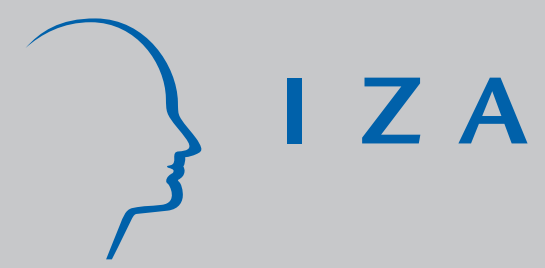

IZA DP No. 7042

Effect of Perceptions and Behaviour on Access to and Use of Financial Service: Evidence from South Africa

Samuel Annim

Thankom Arun

Philip Kostov

November 2012

Forschungsinstitut zur Zukunft der Arbeit Institute for the Study of Labor 


\title{
Effect of Perceptions and Behaviour on Access to and Use of Financial Service: Evidence from South Africa
}

\author{
Samuel Annim \\ University of Central Lancashire \\ Thankom Arun \\ University of Central Lancashire \\ and IZA \\ Philip Kostov \\ University of Central Lancashire
}

Discussion Paper No. 7042

November 2012

\author{
IZA \\ P.O. Box 7240 \\ 53072 Bonn \\ Germany \\ Phone: +49-228-3894-0 \\ Fax: +49-228-3894-180 \\ E-mail: iza@iza.org
}

Any opinions expressed here are those of the author(s) and not those of IZA. Research published in this series may include views on policy, but the institute itself takes no institutional policy positions. The IZA research network is committed to the IZA Guiding Principles of Research Integrity.

The Institute for the Study of Labor (IZA) in Bonn is a local and virtual international research center and a place of communication between science, politics and business. IZA is an independent nonprofit organization supported by Deutsche Post Foundation. The center is associated with the University of Bonn and offers a stimulating research environment through its international network, workshops and conferences, data service, project support, research visits and doctoral program. IZA engages in (i) original and internationally competitive research in all fields of labor economics, (ii) development of policy concepts, and (iii) dissemination of research results and concepts to the interested public.

IZA Discussion Papers often represent preliminary work and are circulated to encourage discussion. Citation of such a paper should account for its provisional character. A revised version may be available directly from the author. 
IZA Discussion Paper No. 7042

November 2012

\section{ABSTRACT}

\section{Effect of Perceptions and Behaviour on Access to and Use of Financial Service: Evidence from South Africa}

This study investigates the effect of financial perception and behaviour on; (a) general accounts and services, (b) investment/savings and (c) insurance/assurance Using FinScope dataset from South Africa over the period 2003 to 2009,ordered probit, generalized ordered probit and pseudo panel micro-econometric techniques have been employed. Results based on all three estimations support the hypothesis that financial perception has a greater effect on the decision to access and use general accounts and services. The cross section and pooled models confirm the hypothesis that the effect of financial behaviour is greater than financial perception when making decisions on the take-up and use of investment financial services. It is also observed that the degree of responsiveness of financial perception on access to, and use of financial services decreases as the depth of usage deepens from basic to advance levels of financial products. In a policy context, targeting demand-side factors to increase access to and use of financial services should be financial type and level specific. Furthermore, the approach should be based on an understanding of the experiences of borrowers.

JEL Classification: O16, O17, G02, O55

Keywords: financial, perception, behaviour, general accounts, investment, insurance, South Africa

Corresponding author:

Thankom Arun

Lancashire Business School

Faculty of Management

University of Central Lancashire

Preston, Lancashire PR1 2HE

United Kingdom

E-mail: tgarun@uclan.ac.uk 


\section{Introduction}

The discourse on financial inclusion seems to have reached a tipping point in terms of the extent to which provision of more, and differentiated financial products can be used to stimulate access to and use of financial services. The supply-side issues have focused on four different aspects of accessibility that is making financial services both available and affordable and designing products in a reliable and flexible manner (Claessens, 2006). In recent times, the debate on the supply-side factors required to engender financial inclusion has paid particular attention to regulation with the aim of protecting consumers and ensuring that emerging financial markets typically, microfinance institutions (MFIs) integrate well into the traditional financial system. In spite of the on-going conscious effort to improve access to finance, financial exclusion still remains high in developing economies. In sub-Saharan Africa (SSA), recent data from the World Bank shows that in 2010, there was 35\% gap between loans acquired from family and friends (40\%) and loans accessed from formal financial institutions (5\%). With the increase in the number of MFIs in SSA, one would have expected a negligible percentage on the acquisition of loans from family and friends. Even in SSA countries where financial inclusion is relatively high, for instance, South Africa, there are emerging concerns on the occasional dips in access and use of financial services. FinMark Trust (2009), based on the 2009 FinScope survey reports that between 2008 and 2009, there were a 3\% fall in the proportion of South Africans that used a bank service. Making financial services accessible and ensuring an enabling environment through a better-quality regulation is therefore, not a sufficient condition to enhance financial performance. Though the supply-side factors are necessary, financial service consumers have been adamant in responding to effective improvement in the supply of financial services.

It is therefore not surprising to observe an increasing trend of financial inclusion studies that focus on the demand-side factors (Bauer et al. 2012 and Kostov et al. 2012). Among the issues that have been explored in this strand of the literature is how self-discipline based on present bias theory (trade-off between current and future preference) and financial perceptions, behaviour and attitudes contribute to financial access and inclusion. Along the lines of these studies this paper explores the relationship between perceptions and behaviour and access to and use of different types and levels of financial services. However, a point of departure between this study and the 
few existing studies is the reliance on a comprehensive measure of financial access and usage. The specific objectives are to; (1) Examine the effect of the financial perception that an individual can live without a bank account on access to and use of; (a) General accounts and services; (b) Insurance and assurance financial products; and (c) investment financial services; (2) Investigate the relationship between an individual's financial behaviour of trading-off the acquisition of basic things for savings and access to and use of; (a) General accounts and services; (b) Insurance and assurance financial products; and (c) investment financial services and (3) estimate and compare the responsiveness of the four outcomes (non-access, basic, intermediate and advance) of each of the financial services, given a change in financial perception and also a change in financial behaviour .

Based on the objectives above, we test the following hypotheses; (1) Compared to financial behaviour, financial perception has a greater effect on access and use of general accounts and services; and (2) In contrast to the above, financial behaviour has a greater effect that financial perception in the case of access to and use of investment and savings products. The premise of the two hypotheses is that across the types of financial services, perceptions are more likely to have an affect on entry-level financial services (general accounts and services) while financial behaviour is relatively more important for higher-level financial service that is investment/savings and insurance/assurance financial services.

The theoretical perspective underlying the reason why a potential borrower will find it less prudent to apply for a loan or engage the services of a financial institution is partly explained by the concept of 'Discouraged Borrower'. Kon and Storey (2003) conceptualize the concept of Discouraged Borrower based on the psychological component of application cost. In this view, Kon and Storey,(2003) indicate that a good borrower - Discouraged borrower - may not apply for a loan to a bank because of a possible rejection. This means that what the borrower thinks perception - about the likely outcome of an application is imperative for achieving the targets of financial inclusion. Indeed, Levenson and Willard (2000) say that the implications of 'discouragement' to access to finance is more important than credit rationing as hypothesized by Stiglitz and Weiss (1981). 
Although the literature on the demand-side is still in its early stages and not well articulated compared to the supply-side issues, factors repeatedly cited to include; (1) borrowers' lack of knowledge/information about their own capabilities and inadequacies, for instance, lack of business and technical skills, (2) negative perceptions, attitudes and behaviour which are largely premised on personal (known) adverse experience with a financial institution and (3) traditional idiosyncratic and covariate risk of poor people. The temptation to associate some of these issues to existing theoretical knowledge impedes our ability to adequately deal with demand-side constraints. For instance, aligning borrowers' lack of knowledge about own skill inadequacies to information asymmetry runs the risk of misfit. This is because the theoretical proposals for dealing with problems arising from information asymmetry (moral hazard and adverse selection) run parallel to a potential solution of business training required to boost skills of borrowers.

The financial landscape in South Africa has changed significantly in the last decade and half. The changes have mainly been identified with regulation and supervision, innovation and outreach and horizontal and vertical synergies (partnership, joint venture and so on) across banks, microfinance institutions (MFIs) and other financial outlets. In terms of financial inclusion, a recent and impacting intervention was the introduction of a bank entry account known as Mzansi. The Mzansi intervention was initiated in 2004 by the four main private banks in South African namely; ABSA, Nedbank, Standard and First National). Leading to the Mzansi interventions were a number of policy and regulatory directives, including the Financial Services Charter (FSC), the National Credit Act (NCA), Financial Advisory and Intermediaries Services Act (2002), and the Financial Services Ombuds Schemes Act (2004).

South Africa's system of financial regulation is based on a single regulator regime with an incline to adopt the "twin peak" financial regulation system to account on the difference in skill sets required for prudential and market conduct regulation. In the context of formal financial institutions, there is also a concerted effort towards a desire to move to the adoption of Basel III in the banking sector. Quite lately, further regulatory interventions include the promulgation of the Consumer Protection (Act No. 68 of 2008) which came into effect on 1 April 2011 and modifications to the existing Broad-based Black Economic Empowerment (BBBEE) Act. The thrust of the former is to promote fair, accessible and sustainable marketplace for consumer products and services. Premised on the South African's political antecedent and racial divide, an 
aspect of the amendment of the BBBEE Act of 2003, stipulates that blacks' access to financial and non-financial services be effectively improved. However, it is worth mentioning that many and conflicting policies and regulations could impede innovations in the sector and constrain attempts to deepen and increase financial access and inclusion.

The rest of the paper is organized as follows; section 2 provides a discussion on the methods used in this study. The last two sections present discussion on the results and conclusion. In the last section, some policy recommendations are provided.

\section{Methods of Study}

This section discusses the source and scope of data used but more importantly explains the procedure for generating the variables, both dependent and explanatory variables. This is followed by a brief description on the econometric technique used, maximum likelihood estimation.

\section{Data}

The current study relies on a repeated cross section data from South Africa, over the period 2003 to 2009. The FinScope survey implemented by FinMark Trust, South Africa was designed to provide an understanding of consumer perceptions and financial behaviour given their resources and living characteristics and patterns. Specifically, 'the overall objective of the FinScope project was to measure effective access to and use of financial services, along with how people manage their money and what drives financial behaviour' (FinScope, 2003; pp. 2). The data is nationally representative and samples individual aged 16 years and above from all the nine provinces in South Africa. Except for the first two rounds of the survey (2003 and 2004) where the sample size for the respective surveys were 2984 and 2988 respectively, 3900 individuals have been interviewed in each round since 2005.

Across the rounds of the survey, the instrument has been largely consistent in terms of scope of issues. The scope of issues in the FinScope survey has been grouped under the following ten headings; (1) Household register; (2) Financial literacy; (3) Overall financial perception; (4) Banking Penetration (transaction channels, Mzansi and credit and loans); (5) Insurance products and services (Funeral cover and retirement/pension); (6) Investment/Savings; (7) Lifestyles; (8) 
Access to amenities and use of information, communication and technology; (9) Sources of money; and (10) Personal and household's socio-economic and demographic characteristics. The consistent coverage of issues over time permits the tracking of financial behaviour albeit the different samples. It is worth mentioning that some slight variation exists based on reclassification and depth of issues being explored.

The fourth, fifth and sixth sections of the FinScope instrument, have been used to measure the extent and nature of financial products and services take-up, and this has been termed as financial penetration (FinScope, 2003). The measure of financial penetration is categorised under three broad headings namely; general accounts and services, investment and savings and insurance and assurance financial products. Access to and use of any of these three types of financial services is grouped into eight tiers. The allocation of tiers was based on analysis that examined how product usage patterns correlated within each component using the Burt matrix/correspondence analysis (FinScope, 2003). Finally, a scree analysis based on the product continuum generated is used to allocate persons into tiers, which indicate the depth of use of use for a particular type of financial service.

The first and second columns of the appendices one, two and three show the respective financial products for each of the three components of financial penetration (general accounts and services, insurance/assurance and investment products) and their scores. This study for the sake of the analysis, re-groups the eight classifications into four (ranging from 0 to 3 ) based on the order of the original groupings. The four categories were respectively labelled as none, basic intermediate and advance access to and use of financial products. The following describes the mapping procedure used. In the case of general accounts and services, the following explains mapping of the scores between the original FinScope data and this study: $(1 \rightarrow 0) ; \quad(2,3$ and $4 \rightarrow 1)$; $(5$ and $6 \rightarrow 2)$; and (7 and $8 \rightarrow 3)$. The mapping used for insurance and assurance products is follows: $(1 \rightarrow 0) ;(2,3,4$ and $5 \rightarrow 1)$; $(6$ and $7 \rightarrow 2)$; and $(8 \rightarrow 3)$. Lastly, in the case of investment products the following mapping approach was used: $(1 \rightarrow 0)$; $(2$ and $3 \rightarrow 1) ;(4,5$ and $6 \rightarrow 2)$; and $(7$ and $8 \rightarrow 3)$. The criteria for mapping as mentioned earlier primarily based on the original scoring by FinScope but they are tweaked a bit depending distribution of scores and the correlation coefficient between the 
financial penetration score ${ }^{1}$ in the original FinScope data and our study. The minimum correlation coefficient recorded across the three measures for each of the rounds of survey was 0.84 . This indicates that our reclassification is similar to that of the original survey.

The variables on financial perception and behaviour were ascertained directly from the instrument based on following questions: (1) You can easily live your life without having a bank account and (2) You go without basic things in order to save (TNS Research Survey, 2009). The expectation is that individuals with the perception that they can easily live without having a bank account are less likely to access any of the financial services more especially, general accounts and services. In terms of behaviour, individuals who save at the expense of basic more likely to access all the financial services especially investment and savings and insurance and assurance products. For the sake of easy interpretation and uniform sign for the coefficients of both variables, the study captures a dummy variable with a response equal to one if the individual disagrees with the notion that one can easily live life without having a bank account - positive financial perception - and equal to one also, if the respondent saves at the expense of basic things - positive financial behaviour -. This implies that a positive coefficient is expected in each of the case

The study controls for other variables in the model, two of these variables are; access to financial services captured by distance to formal financial and reasons for not banking; and life circumstances, major events, happiness and connectedness. Both variables are captured on a scale ranging from one to eight and have been explained in detail in FinScope (2003). Given that it is a summary measure, interpretation of coefficients requires caution. Other explanatory variables are; education, income, age, marital status, race and household size. To account for other community level's effects that might affect access and use of any of the types of financial services, we controlled for province effects.

\section{Econometric Estimation}

The econometric techniques used for this study are the ordered and generalised ordered probit models. To verify the robustness of our estimates, we pool the data across the rounds and also generate a pseudo panel to address heterogeneity bias. Though the panel is synthetic because the same individuals are not re-interviewed over the rounds, this technique allows us to address the

\footnotetext{
${ }^{1}$ The financial penetration score in the FinScope data is a simple average of the highest score of an individual for each of the three types of financial services (FinScope, 2003).
} 
self-constructed cohort effects that are either strictly exogenous or partially endogenous to our model specification. The next two sub-sections elaborate further on the econometric estimations.

The choice of ordered probit over 'ordinary' probit and multinomial models is because the dependent variable ranked from 0 to 3 . As indicated, the different levels indicate the extent of financial service take-up. In addition to the ordered probit model, we estimate a generalized ordered probit model. This is because of the strict parallel lines or proportional odds assumption ${ }^{2}$ that premise the estimation of ordered probit models. The generalized ordered probit model is used to overcome this overly restrictive assumption by estimating a partial proportional odds model in which case some coefficients can be the same for all values of the outcome of the dependent variable, while other vary (Williams, 2006). Also, since the generalized ordered probit model yields more coefficients similar to the case of estimating a series of binary outcomes, but conditioned on the partial proportional odds assumptions it provides a platform to examine patterns that are obscure with ordered probit estimation. Lastly, this study uses a revised version of the generalized ordered probit estimation (gologit2 in stata) which provides an opportunity to conduct several post-estimation tests and flexibility of choosing a significance level that will inform the decision on which variables to constrain or otherwise (Williams, 2006).

In this study, the variables that needed to be constrained to meet the parallel lines assumptions were identified following a post-estimation test ${ }^{3}$ conducted after the ordered probit estimation. For the sake of consistency across the rounds of the survey, the same set of variables was used for a given type of financial service. The following is the list of variables constrained for each of the three types of financial services: (1) In the case of general accounts and services the variables were; physical access to formal financial institutions, financial perception, financial behaviour, income and province effects; (2) For investment/savings products; optimism, race, financial behaviour, financial perception and province effect were constrained; (3) With Insurance/Assurance products, financial behaviour, financial perception; physical access to formal financial institutions, optimism, income and race were made to meet the parallel lines assumption.

\footnotetext{
2 This means that the coefficients should be the same across all the estimations for each outcome of the dependent variable.

${ }^{3}$ We use the brant routine in Stata to test for variables that violate the parallel line assumption. Significant variable means that the parallel regression assumption has been violated.
} 
To validate our econometric estimates beyond the usual post-estimation tests, as has been done with both the ordered probit and generalized ordered probit models, we attempt to minimize any possible bias associated with unobserved unit -specific characteristics. In this study, the unit is the person, however since the same persons were not re-interviewed across the different rounds of the FinScope data, we are unable to use a real panel to capture person-specific effects. In view of this, we generate a pseudo-panel, which is based on age-categories and province in each round of the survey. The motivation to correct for unobserved heterogeneity is that even in the case of linear models, given the nature of correlation (positive or negative) between unit specific unobserved effect and any of the explanatory variables in a model and the dependent variable, estimated coefficients may be biased downwards or upwards. Holm et al. (2008) say that the biased in non-linear models is more daunting as the estimated coefficients will still be bias even in the case where the unobserved unit specific effect is not correlated with the explanatory variables.

Deaton (1986) makes a case for generating a pseudo panel ${ }^{4}$ when more than one cross- section data has a common variable, for example, age, education and location. The use of such variables is premised on the assumption that the classifications rarely change over time, and they are exogenously determined outside the model. In this study, we generate a pseudo using age and province for each round of the survey. This implies that our sample reduces to 630 (10 age-categories $* 9$ provinces $* 7$ rounds of the survey ${ }^{5}$ ).

\section{Results and Discussion}

The descriptive statistics in Appendices 1, 2 and 3, show that the proportion of South Africans who did not have access to any of the products of general accounts and services decreased by almost a fifth over the period 2003 and 2009. The analysis for investment and savings and products are limited to the period 2003 to 2007 as the reclassification of the products in 2008 and later years are not consistent with the earlier years. The trend of the proportion of adults aged 16 and above who did not have any investment and savings financial products increased consistently from 2003 to 2006 until a sharp drop in 2007. This observed trend is worth investigating in terms factors that accounted for the drop of about $63 \%$ between the period 2006

\footnotetext{
${ }^{4}$ For further detailed discussion on the use and suitability of pseudo panel see Verbeek (1992) and Verbeek and Nijman (1996)

5 The investment models run from 2003 to 2007 hence the sample for the pseudo panel is 450 .
} 
and 2007. Large variations are also observed for the proportion of adults aged 16 and above who had access to and used basic investment and savings products. As a recall some of the basic investment and savings products include: lending to others and benefiting from their profit/interest and being a member of either Stokvel/ savings club or Burial society. The trend shows that access to use of these basic investments, and savings financial products was fairly constant over the period 2003 and 2006 but increased by about 67\% over the period 2006 and 2007. In terms of insurance and assurance financial products the proportion of adults aged 16 and above who were not using as well as those who had access and were using remained relatively constant over the period 2003 and 2009. The variation in trends of penetration across the three types of financial services stimulates the econometric analysis that seeks to provide answers on the reasons for the changes.

Appendix 4, presents the trend of our main explanatory variables that is, financial perception and financial behaviour. Comparing columns 2 and 3, the proportion of respondents with the perception that having a bank account is relevant was greater than the proportion of respondents that traded-off basic things in order to save. The T-Test for the difference in proportions highlights the statistical significance of the difference between financial perception and financial behaviour. Although the proportions for both financial perceptions and financial behaviour was fairly constant over time, a notable observation is that between 2006 and 2007, the proportion of respondents with the perception that having a bank account is important leap frogged by $0.06 \%$. This difference compared to changes for the other pairs of successive years was huge.

As a recall, we test the following hypotheses; (1) Compared to financial behaviour, financial perception has a greater effect on access to and use of general accounts and services; and (2) In contrast to the above, financial behaviour has a greater effect that financial perception in the case of access to and use of investment and savings products..

Tables 1 to 3 below present the ordered regression results for each of the three types of financial penetration components namely; general accounts and services, investment/savings and insurance/assurance financial products. For each of the three types of financials services, Tables 1 to 3 , offer an overview of the trend of coefficients and statistical significance of our explanatory variables especially, the finance perception and behaviour variables. Table 1 shows that financial perception significantly influences the decision to access and use general accounts 
and services. This observation is consistent across the all eight estimations (2003 - 2009 and the pooled analysis). This literally means that the perception that one can live without a bank account reduces the likelihood of accessing and using any form of general accounts and services product. Similar results are observed in the case of financial behaviour with the exception for that the coefficient for the first round (2003) is not significant. Thus our initial observation is that both financial perception and behaviour are likely to influence the decision to access and use general account and services.

\section{Insert Table 1 Here}

In the context of the study's first hypothesis, a critical observation of the coefficients shows that for each round of the analysis, the coefficient of financial perception is greater than that of financial behaviour. This means that perception influences the decision to access and use general accounts and services more than behaviour.

Table 2 presents the results for the second component of financial penetration - investment and savings products -and the results support the hypothesis that the decision to investment or save is affected relatively more by financial behaviour than financial perception. Comparing the statistical significance of the two main explanatory variables across the six different estimations, it is observed that the effect of financial perception on investment and saving decisions is not always significant compared to the effect of financial behaviour. More importantly, in instances where the coefficient is positive as expected for both financial perception and behaviour, the coefficient of the latter is greater than the former. Hence financial perception is less important for higher levels of financial transactions.

\section{Insert Table 2 Here}

The results for access to and use of insurance/assurance financial products are presented in Table 3. Similar to the results obtained in the case of access to and use of general accounts and services, we observe that financial perception with the exception of the third round (2005) is positive and statistically significant. Compared to financial behaviour, only four of the eight estimations show the expected sign and statistical significance. In three of these cases, the coefficient of financial perception is greater than that of financial behaviour. This suggests the decision to take-up an insurance/assurance product is largely influenced by financial perception. 


\section{Insert Table 3 Here}

Across the three types of financial services, almost all the explanatory variables showed the expected sign and were statistically significant. Notable of the explanatory variables are: physical access to formal financial services and reasons for not having access; education, income, race and marital status. The observed positive coefficient of physical access confirms the need to make financial services available to users. That is living close to a financial institution increases the probability of access any of the three types of financial services. It is worth mentioning that the coefficient is significantly higher in the case of access to general accounts and services and insurance and assurance than investment and savings products. More importantly, in the third and fourth rounds (2005 and 2006) the coefficients of physical access of formal financial services are not statistically significant. Although, the comparison has some caveats given that the models are different the huge differences incite concern for future analysis.

The expected positive effect of university education compared to no or primary schooling on access to and use of financial services is confirmed. The results of a positive and statistical significant coefficient are observed across all the rounds for each component of financial service but 2006 in the case of investment and savings products. Similar to education, higher income compared no income consistently show a positive and statistical significant coefficient on access to and use of financial services.

In terms of users' optimism, despite the complexity in measurement, there are some evidence to support the conjecture that people's circumstances (access to basic amenities, health and work and social environment); perceived level of needs of satisfaction and overall happiness positively affects the decision to access and use a financial service.

The third objective - estimate and compare the elasticities of the four outcomes (non-access, basic, intermediate and advance) of each of the financial services, given a change in financial perception and also a change in financial behaviour - is addressed based on the estimation of a generalized ordered probit model, and the results are presented Tables $4-6$. To arrive at the degree of responsiveness of the four different outcomes of our dependent variables, the marginal effects of the estimated coefficients are presented. For the sake of brevity, we present the results of our two 
main explanatory variables that is financial perception - notion that one can live without a bank account - and financial behaviour - trade-off basic things in order to save.

Interpretation of Tables $4-6$ underscores the differences in the degree of responsiveness across the levels of each financial service (rows A, B, C and D) but this is done in comparison with the trends (columns $1-8$ ). Table 4 presents the case of general accounts and services.

\section{Insert Table 4 Here}

Row A, column 1 of Table 4 shows that about one out of every ten people with the perception that bank account is relevant is less likely not to have any form of general accounts and services product. The tide changes with the effect of financial perception on having a basic account (Mzansi, ATM, Savings Book, Post Office Account, Savings and Transaction Account Loan of a Friend, Employer or Microcredit Institution), intermediate account (Debit Card, Current or cheque account, Credit Card, Fixed Deposit, Mortgage, Money for house either from Government or Employer and Personal Loan) or advance account (Money Market, Vehicle Finance or Overdraft). That is, from Table 4, row B, we observe that comparing individual's perception on the relevance of having a bank account, a positive perception is associated with a 7.3\% increase in the likelihood of having a basic general accounts and services. However, a notable observation is that the degree of responsiveness of financial perception on the importance of having a bank account on access to and use of general accounts decreases as we move from basic accounts to advance accounts.

Examining the above observation over time, there is a turnaround of the effect of financial perception on basic account and intermediate account for the period 2007 to 2009 . In fact, $t$ in 2008, while row B shows that the perception on the relevance of a bank account is associated with a $4.1 \%$ lower chance of accessing and using basic general accounts and services however, in row C, for the same year (2008) a higher probability of $11 \%$ is identified with the effect of financial perception on intermediate account. This indicates that the role of perceptions is not only basic

level accounts, but also for higher levels of general accounts and services. This pattern is also observed for the 2009 survey. Matching the period of the turn-around of the degree of responsiveness of access to and use of basic and intermediate accounts to changes in financial perception with the $0.06 \%$ change between 2006 and 2007 for the proportion of respondents with the view that having a bank account is relevant (Appendix 4), one can surmise that the turn-around 
is possibly associated with the change. Although the current study, does not allow for attribution, such associations provide a platform for a more careful investigation between the changes in financial perception and access to and use of different financial services.

Table 5, compares the effect of financial perception and financial behaviour across the different levels of investment and savings financial products. The marginal effects confirm the second hypothesis that the effect of financial behaviour of the decision to access and use investment savings and product is more significant and greater than financial perceptions. Across all the years, we observe that the effect of financial behaviour decreases with greater depth on access to and use of investment and savings financial products. That is the degree of responsiveness of access to and use of advance investment and savings products (Timeshares, Holiday home/investment in a second home, Investment in vacant land, farm land, own business, someone else's business, shares on the stock market and off-shore investment) to change in behaviour of trading-off basic things in order to save is much lower than that the degree of responsiveness to access to and use of basic investment and savings products (lending to other and benefitting from their profit and being a member of Stokvel/savings club or burial society).

\section{Insert Table 5 Here}

In the case of the responsiveness of access to use of insurance/assurance financial products, the effect of financial perception on each of the four outcomes namely: none; basic (Funeral Policy with a big institution, Provident or Pension Fund and Educational Policy); intermediate (Life Assurance Policy, Retirement Annuity, Endowment/Investment Policy, Homeowner's insurance, Medical Aid, Insurance taken out to maintain credit payments and Car Insurance); and advance (Hospital Plan and Medical or Household content Insurance) is more significant and greater than the effect of financial behaviour (Table 6, below). Over time, two broad patterns of the effect of both financial perception and financial behaviour are observed. The period before 2008 indicates that the effect of both financial perception and financial behaviour decreases with greater depth (moving from basic to advance insurance/assurance financial products) of accessing and using insurance/assurance products. However, for the period 2008 and 2009, there is an indication that the responsiveness of intermediate insurance/assurance products for a given change in both financial perception and financial behaviour is greater than the effect on basic insurance/assurance 
products. The effect of advanced insurance/assurance financial products remains relatively low and this finding is consistent across all rounds of the survey.

The degree of responsiveness for either financial perception or financial behaviour for each level over time fails to reveal any discernible pattern. The coefficients largely fluctuate over time.

\section{Insert Table 6 Here}

The results to verify the reliability of our estimates via a pseudo panel analysis are presented in Table 7. In interpreting pseudo panel results, we will highlight the post-estimation tests at the bottom of Table 7 to inform the choice of a regression result. The F-statistics for the cohort effects (null hypothesis is that there is no variation across the panel generated) is significant for the general accounts and services and insurance/assurance models but not the investment/savings model. This means that the unobserved cohort specific effects are worth correcting in the case of general accounts and services and insurance/assurance models. Based on this, we will concentrate on columns 1 and 2 for the general accounts and services and columns 3 and 4 for insurance/assurance. In each of these two cases the Hausman Test suggests that the fixed effect models are preferred to the random effect models, hence our focus will be columns 1 and 5 for general accounts and services and insurance/assurance respectively.

In column 1 of Table 7 fairly consistent results are observed in comparison with the individual cross sections and the pooled results earlier presented in the text. The two main explanatory variables show that financial perception and financial behaviour significantly affect the decision to access and use a financial service. In column 5, we find a non-significant relationship between financial behaviour and access to and use of insurance/assurance financial products. That is, after correcting for unobserved effect financial behaviour fails to explain access to and use of insurance/assurance financial products. We find a positive relationship between financial perception and access to and use of insurance/assurance financial products, but worth commenting is that the level of significance is only $10 \%$.

This finding corroborates the robustness of the effect of financial perception and behaviour on access to and use of general accounts and services. Furthermore, the effect of financial perception on insurance/assurance is confirmed. In the case of the investment/savings model, we have to rely on the cross section and pooled results to say that there is a relationship between financial 
perception and behaviour on access to and use of investment/savings financial products. Further estimations using alternative methods for checking unobserved heterogeneity such as finite mixture binary logit model will be carried out in the future. Finally, based on the non-significance of the effect of financial behaviour on access to and use of insurance/assurance products, we caution advocacy on the issue of association between the two variables.

\section{Insert Table 7 Here}

\section{Conclusion}

The study has explored the effect of financial perceptions and behaviour on access to and use of different types and levels of financial services in South Africa. On a pessimistic note that the gains of increasing the supply of financial services have far been outstripped, this study is motivated to examine the demand-side factors that are likely to affect the decision to access and use different types financial services and levels of financial products. The main objectives of the study were to: (1) Examine the effect of the financial perception that an individual can live without a bank account on access to and use of; (a) General accounts and services; (b) Insurance and assurance financial products; and (c) investment financial services; (2) Investigate the relationship between an individual's financial behaviour of trading-off the acquisition of basic things for savings and access to and use of; (a) General accounts and services; (b) Insurance and assurance financial products; and (c) investment financial services and (3) Estimate and compare the responsiveness of the four outcomes (non-access, basic, intermediate and advance) of each of the financial services, given a change in financial perception and also a change in financial behaviour.

Our main finding is that there is a robust relationship between financial perception and behaviour on access to and use of general accounts and services and between financial perception and access to and use of insurance/assurance products. Results based on all three estimations support the hypothesis that financial perception affects the decision to access and use general accounts and services. The cross section and pooled non-linear models also confirm the hypothesis that the effect of financial behaviour is greater than financial perception in making decisions related to the take-up and use of investment/savings financial services. In addition to these two hypotheses, the study also estimated and compared the degree of responsiveness of different levels of financial products. That is, with each component of financial service, access to and uses of financial products were categorized into four outcomes namely; non-use, basic, intermediate and advanced 
depending on the extent of usage. The broad finding was that the degree of responsiveness of financial perception on access and use of financial services decreased as the depth of usage deepened from basic to advance levels of financial products. However, since 2008, the effect of financial perception on intermediate accounts for general accounts and services and insurance/assurance financial products have been greater than the effect on basic accounts.

In a policy context, we recommend demystification of negative perceptions that inhibit the use of financial services especially, general accounts and services. Also imperative to the course of stimulating demand for financial service is the need to design financial curative advocacy strategies to deal with formed behaviours that constrain the use of financially services notably, investment products. That is, synonymous to health curative measures, financial curative measures should go through a diagnostic stage with the aim of providing a dossier on (1) borrowers personal and known experiences (2) borrowers' cost associated with financial exclusion and (3) benefits of financial inclusion to the borrower. This dossier then can be used as an advocacy tool to change financial behaviour to engender financial inclusion. Finally, the observed limits of financial perception and behaviour in influencing higher-level (advance) financial services to imply that incentive mechanisms from the supply-side are imperative as a complementary strategy for improving financial access and inclusion.

\section{References}

Bauer M., Chytilova J. and Morduch J. (2012) "Behavioral Foundations of Microcredit: Experimental and Survey Evidence from Rural India" American Economic Review 102(2): 1118-1139 
Claessens, S. (2006) "Access to financial services: A review of the issues and public policy objectives” World Bank Research Observer 21(2): 207-240

Deaton A. (1986) 'Panel Data from a Time Series of Cross Sections', Journal of Econometrics, 30, pp. $109-126$

FinMark Trust (2009) 'Survey Highlights including FSM Model FinScope South Africa 2009' Johannesburg, South Africa

FinScope (2003) 'Understanding the (Prototype) Financial Summary Measure (FSM)' Research Surveys (Pty) Ltd, http://www.finscope.co.za/documents/2003/FSM_Writeup.pdf, Accessed on $10^{\text {th }}$ February 2010

Holm A., JægerM. M. and PedersenM. (2008) 'Unobserved Heterogeneity in the Binary Logit Model with Cross-Sectional Data and ShortPanels: A Finite Mixture Approach' Centre for Applied Microeconometrics Working paper no. 2009-04, University of Copenhagan, http://www.econ.ku.dk/cam/wp0910/2009-04.pdf/ Accessed 28/11/11

Kon Y. and Storey D.J. (2003) 'A Theory of Discouraged Borrower' Small Business Economics 21: $37-49$

Kostov P. , Arun T. and Annim S. K. (2012) 'Determinants of Access to Finance: An Investigation into the Mzansi Intervention' European Journal of Development Research24, 397412. doi:10.1057/ejdr.2011.59

Levenson A. R. and Willard K.L. (2000) 'Do Firms Get Financing They Want? Measuring Credit Rationing Experienced by Small Business in the US' Small Business Economics 14(2), 83 $-94$

Stiglitz J. and Weiss A. (1981) 'Credit rationing in Markets with Imperfect Information' American Economic Review 71(3), 393 - 410

TNS Research Survey (2009) 'Project FinScope SA 2009 Questionnaire Job No: SHU 4120' South Africa 
Verbeek, M. (1996) Pseudo Panel Data in Matyas, L. \&Sevestre, P. (Eds.), The Econometrics of Panel data: A Handbook of the Theory with Applications, Second Edition, in Advanced Studies in Theoretical and Applied Econometrics, 33: 280-92 (Boston and London, KluwerAcademic)

Verbeek, M. \&Nijman T. E. (1992) 'Can Cohort Data Be Treated As Genuine Panel Data?’

Empirical Economics 17:9-23

Williams R. (2006) 'Generalized Ordered Logit/ Partial proportional Odds Models for Ordinal Dependent Variables' The Stata Journal 6(1): 58 - 82 
Table 1: Ordered Logit Estimation of Access to General Accounts and Service

\begin{tabular}{|c|c|c|c|c|c|c|c|c|}
\hline \multirow{2}{*}{ Explanatory Variables } & (1) & (2) & (3) & (4) & (5) & (6) & (7) & (8) \\
\hline & 2003 & 2004 & 2005 & 2006 & 2007 & 2008 & 2009 & pool \\
\hline $\begin{array}{l}\text { Disagree with the notion that one } \\
\text { can live without a bank account }\end{array}$ & $\begin{array}{l}0.641 \\
{[6.03]^{* *}}\end{array}$ & $\begin{array}{l}0.596 \\
{[5.87]^{* *}}\end{array}$ & $\begin{array}{l}0.470 \\
{[5.18]^{* *}}\end{array}$ & $\begin{array}{l}0.665 \\
{[7.64]^{* *}}\end{array}$ & $\begin{array}{l}0.578 \\
{[7.05]^{* *}}\end{array}$ & $\begin{array}{l}0.618 \\
{[7.56]^{* *}}\end{array}$ & $\begin{array}{l}0.574 \\
{[7.29]^{* *}}\end{array}$ & $\begin{array}{l}0.542 \\
{[17.13]^{* *}}\end{array}$ \\
\hline $\begin{array}{l}\text { Trade-off basic things in order to } \\
\text { save }\end{array}$ & $\begin{array}{l}0.174 \\
{[1.56]}\end{array}$ & $\begin{array}{l}0.484 \\
{[4.45]^{* *}}\end{array}$ & $\begin{array}{l}0.211 \\
{[2.25]^{*}}\end{array}$ & $\begin{array}{l}0.525 \\
{[5.52]^{* *}}\end{array}$ & $\begin{array}{l}0.313 \\
{[3.49]^{* *}}\end{array}$ & $\begin{array}{l}0.232 \\
{[2.72]^{* *}}\end{array}$ & $\begin{array}{l}0.379 \\
{[4.19]^{* *}}\end{array}$ & $\begin{array}{l}0.321 \\
{[9.47]^{* *}}\end{array}$ \\
\hline Optimism & $\begin{array}{l}0.166 \\
{[3.54]^{* *}}\end{array}$ & $\begin{array}{l}0.067 \\
{[1.46]}\end{array}$ & $\begin{array}{l}0.056 \\
{[1.38]}\end{array}$ & $\begin{array}{l}0.074 \\
{[1.82]+}\end{array}$ & $\begin{array}{l}-0.005 \\
{[-0.11]}\end{array}$ & $\begin{array}{l}0.089 \\
{[2.31]^{*}}\end{array}$ & $\begin{array}{l}0.009 \\
{[0.22]}\end{array}$ & $\begin{array}{l}0.075 \\
{[5.02]^{* *}}\end{array}$ \\
\hline $\begin{array}{l}\text { Physical access to formal financial } \\
\text { institutions }\end{array}$ & $\begin{array}{l}0.771 \\
{[25.85]^{* *}}\end{array}$ & $\begin{array}{l}0.746 \\
{[25.23]^{* *}}\end{array}$ & $\begin{array}{l}0.814 \\
{[34.01]^{* *}}\end{array}$ & $\begin{array}{l}0.834 \\
{[27.77]^{* *}}\end{array}$ & $\begin{array}{l}0.668 \\
{[28.71]^{* *}}\end{array}$ & $\begin{array}{l}0.749 \\
{[30.77]^{* *}}\end{array}$ & $\begin{array}{l}0.340 \\
{[16.59]^{* *}}\end{array}$ & $\begin{array}{l}0.641 \\
{[71.52]^{* *}}\end{array}$ \\
\hline High School ${ }^{1}$ & $\begin{array}{l}0.422 \\
{[3.26]^{* *}}\end{array}$ & $\begin{array}{l}0.167 \\
{[1.35]}\end{array}$ & $\begin{array}{l}0.539 \\
{[4.07]^{* *}}\end{array}$ & $\begin{array}{l}0.313 \\
{[2.51]^{*}}\end{array}$ & $\begin{array}{l}0.172 \\
{[1.41]}\end{array}$ & $\begin{array}{l}0.323 \\
{[2.40]^{*}}\end{array}$ & $\begin{array}{l}0.244 \\
{[1.97]^{*}}\end{array}$ & $\begin{array}{l}0.291 \\
{[6.47]^{* *}}\end{array}$ \\
\hline Matriculation and Some University & $\begin{array}{l}1.024 \\
{[6.63]^{* *}}\end{array}$ & $\begin{array}{l}0.711 \\
{[4.80]^{* *}}\end{array}$ & $\begin{array}{l}1.040 \\
{[6.92]^{* *}}\end{array}$ & $\begin{array}{l}0.795 \\
{[5.38]^{* *}}\end{array}$ & $\begin{array}{l}0.569 \\
{[4.60]^{* *}}\end{array}$ & $\begin{array}{l}0.713 \\
{[5.18]^{* *}}\end{array}$ & $\begin{array}{l}0.399 \\
{[3.09]^{* *}}\end{array}$ & $\begin{array}{l}0.731 \\
{[14.61]^{* *}}\end{array}$ \\
\hline University completed and above & $\begin{array}{l}1.862 \\
{[5.87]^{* *}}\end{array}$ & $\begin{array}{l}1.078 \\
{[3.27]^{* *}}\end{array}$ & $\begin{array}{l}1.493 \\
{[5.46]^{* *}}\end{array}$ & $\begin{array}{l}1.479 \\
{[5.53]^{* *}}\end{array}$ & $\begin{array}{l}0.792 \\
{[3.12]^{* *}}\end{array}$ & $\begin{array}{l}0.807 \\
{[3.10]^{* *}}\end{array}$ & $\begin{array}{l}0.957 \\
{[3.91]^{* *}}\end{array}$ & $\begin{array}{l}1.247 \\
{[12.48]^{* *}}\end{array}$ \\
\hline $25-29$ years $^{2}$ & $\begin{array}{l}0.633 \\
{[3.35]^{* *}}\end{array}$ & $\begin{array}{l}0.119 \\
{[0.65]}\end{array}$ & $\begin{array}{l}0.219 \\
{[1.47]}\end{array}$ & $\begin{array}{l}0.550 \\
{[3.47]^{* *}}\end{array}$ & $\begin{array}{l}0.320 \\
{[2.40]^{*}}\end{array}$ & $\begin{array}{l}0.397 \\
{[2.80]^{* *}}\end{array}$ & $\begin{array}{l}0.410 \\
{[3.15]^{* *}}\end{array}$ & $\begin{array}{l}0.366 \\
{[6.68]^{* *}}\end{array}$ \\
\hline $30-34$ years & $\begin{array}{l}0.630 \\
{[3.30]^{* *}}\end{array}$ & $\begin{array}{l}0.410 \\
{[2.15]^{*}}\end{array}$ & $\begin{array}{l}0.357 \\
{[2.26]^{*}}\end{array}$ & $\begin{array}{l}0.508 \\
{[3.30]^{* *}}\end{array}$ & $\begin{array}{l}0.347 \\
{[2.46]^{*}}\end{array}$ & $\begin{array}{l}0.665 \\
{[4.67]^{* *}}\end{array}$ & $\begin{array}{l}0.384 \\
{[2.64]^{* *}}\end{array}$ & $\begin{array}{l}0.463 \\
{[8.14]^{* *}}\end{array}$ \\
\hline $35-39$ years & $\begin{array}{l}0.883 \\
{[4.71]^{* *}}\end{array}$ & $\begin{array}{l}0.151 \\
{[0.78]}\end{array}$ & $\begin{array}{l}0.600 \\
{[3.68]^{* *}}\end{array}$ & $\begin{array}{l}0.795 \\
{[5.01]^{* *}}\end{array}$ & $\begin{array}{l}0.517 \\
{[3.48]^{* *}}\end{array}$ & $\begin{array}{l}0.506 \\
{[3.35]^{* *}}\end{array}$ & $\begin{array}{l}0.457 \\
{[3.06]^{* *}}\end{array}$ & $\begin{array}{l}0.546 \\
{[9.35]^{* *}}\end{array}$ \\
\hline $40-44$ years & $\begin{array}{l}0.790 \\
{[3.78]^{* *}}\end{array}$ & $\begin{array}{l}0.672 \\
{[3.28]^{* *}}\end{array}$ & $\begin{array}{l}0.741 \\
{[4.17]^{* *}}\end{array}$ & $\begin{array}{l}0.366 \\
{[2.03]^{*}}\end{array}$ & $\begin{array}{l}0.413 \\
{[2.59]^{* *}}\end{array}$ & $\begin{array}{l}0.775 \\
{[4.81]^{* *}}\end{array}$ & $\begin{array}{l}0.382 \\
{[2.53]^{*}}\end{array}$ & $\begin{array}{l}0.561 \\
{[8.87]^{* *}}\end{array}$ \\
\hline $45-49$ years & $\begin{array}{l}1.121 \\
{[5.14]^{* *}}\end{array}$ & $\begin{array}{l}0.365 \\
{[1.65]+}\end{array}$ & $\begin{array}{l}0.644 \\
{[3.75]^{* *}}\end{array}$ & $\begin{array}{l}0.692 \\
{[3.86]^{* *}}\end{array}$ & $\begin{array}{l}0.434 \\
{[2.54]^{*}}\end{array}$ & $\begin{array}{l}0.613 \\
{[3.74]^{* *}}\end{array}$ & $\begin{array}{l}0.472 \\
{[2.77]^{* *}}\end{array}$ & $\begin{array}{l}0.591 \\
{[8.90]^{* *}}\end{array}$ \\
\hline $50-54$ years & $\begin{array}{l}1.155 \\
{[5.03]^{* *}}\end{array}$ & {$[1.96]^{*}$} & $\begin{array}{l}0.718 \\
{[3.59]^{* *}}\end{array}$ & {$[1.65]+$} & $\begin{array}{l}0.446 \\
{[2.12]^{*}}\end{array}$ & $\begin{array}{l}0.598 \\
{[2.96]^{* *}}\end{array}$ & $\begin{array}{l}0.584 \\
{[3.31]^{* *}}\end{array}$ & $\begin{array}{l}0.588 \\
{[7.98]^{* *}}\end{array}$ \\
\hline $55-59$ years & $\begin{array}{l}0.972 \\
{[3.56]^{* *}}\end{array}$ & $\begin{array}{l}0.925 \\
{[3.45]^{* *}}\end{array}$ & $\begin{array}{l}0.569 \\
{[2.66]^{* *}}\end{array}$ & $\begin{array}{l}0.550 \\
{[2.63]^{* *}}\end{array}$ & $\begin{array}{l}0.137 \\
{[0.63]}\end{array}$ & $\begin{array}{l}0.366 \\
{[1.79]+}\end{array}$ & $\begin{array}{l}0.440 \\
{[2.15]^{*}}\end{array}$ & $\begin{array}{l}0.554 \\
{[6.76]^{* *}}\end{array}$ \\
\hline $60-64$ years & $\begin{array}{l}1.140 \\
{[3.98]^{* *}}\end{array}$ & $\begin{array}{l}0.386 \\
{[1.72]+}\end{array}$ & $\begin{array}{l}0.404 \\
{[1.71]+}\end{array}$ & $\begin{array}{l}0.276 \\
{[1.04]}\end{array}$ & $\begin{array}{l}0.241 \\
{[1.07]}\end{array}$ & $\begin{array}{l}0.177 \\
{[0.79]}\end{array}$ & $\begin{array}{l}0.251 \\
{[1.21]}\end{array}$ & $\begin{array}{l}0.374 \\
{[4.37]^{* *}}\end{array}$ \\
\hline $65+$ years & $\begin{array}{l}0.870 \\
{[3.85]^{* *}}\end{array}$ & $\begin{array}{l}0.492 \\
{[2.35]^{*}}\end{array}$ & $\begin{array}{l}0.559 \\
{[3.09]^{* *}}\end{array}$ & $\begin{array}{l}0.237 \\
{[1.29]}\end{array}$ & $\begin{array}{l}0.072 \\
{[0.37]}\end{array}$ & $\begin{array}{l}0.024 \\
{[0.12]}\end{array}$ & $\begin{array}{l}0.267 \\
{[1.58]}\end{array}$ & $\begin{array}{l}0.341 \\
{[4.98]^{* *}}\end{array}$ \\
\hline Below Average Income ${ }^{3}$ & $\begin{array}{l}0.520 \\
{[3.72]^{* *}}\end{array}$ & $\begin{array}{l}0.559 \\
{[3.88]^{* *}}\end{array}$ & $\begin{array}{l}0.379 \\
{[2.96]^{* *}}\end{array}$ & $\begin{array}{l}0.508 \\
{[4.39]^{* *}}\end{array}$ & $\begin{array}{l}0.286 \\
{[2.32]^{*}}\end{array}$ & $\begin{array}{l}0.606 \\
{[4.80]^{* *}}\end{array}$ & $\begin{array}{l}0.565 \\
{[4.55]^{* *}}\end{array}$ & $\begin{array}{l}0.449 \\
{[9.74]^{* *}}\end{array}$ \\
\hline Average Income & $\begin{array}{l}0.910 \\
{[5.20]^{* *}}\end{array}$ & $\begin{array}{l}1.065 \\
{[6.37]^{* *}}\end{array}$ & $\begin{array}{l}0.877 \\
{[5.26]^{* *}}\end{array}$ & $\begin{array}{l}1.303 \\
{[8.37]^{* *}}\end{array}$ & $\begin{array}{l}0.787 \\
{[5.98]^{* *}}\end{array}$ & $\begin{array}{l}0.750 \\
{[5.60]^{* *}}\end{array}$ & $\begin{array}{l}0.752 \\
{[5.80]^{* *}}\end{array}$ & $\begin{array}{l}0.859 \\
{[16.18]^{* *}}\end{array}$ \\
\hline Above Average Income & $\begin{array}{l}2.088 \\
{[10.14]^{* *}}\end{array}$ & $\begin{array}{l}2.022 \\
{[10.10]^{* *}}\end{array}$ & $\begin{array}{l}1.835 \\
{[10.53]^{* *}}\end{array}$ & $\begin{array}{l}1.843 \\
{[10.76]^{* *}}\end{array}$ & $\begin{array}{l}1.384 \\
{[10.07]^{* *}}\end{array}$ & $\begin{array}{l}1.140 \\
{[8.53]^{* *}}\end{array}$ & $\begin{array}{l}0.997 \\
{[7.91]^{* *}}\end{array}$ & $\begin{array}{l}1.511 \\
{[25.79]^{* *}}\end{array}$ \\
\hline High Income & $\begin{array}{l}1.630 \\
{[3.00]^{* *}}\end{array}$ & $\begin{array}{l}2.594 \\
{[3.98]^{* *}}\end{array}$ & $\begin{array}{l}3.203 \\
{[10.06]^{* *}}\end{array}$ & $\begin{array}{l}3.040 \\
{[10.89]^{* *}}\end{array}$ & $\begin{array}{l}2.794 \\
{[13.70]^{* *}}\end{array}$ & $\begin{array}{l}2.838 \\
{[14.27]^{* *}}\end{array}$ & $\begin{array}{l}3.161 \\
{[13.04]^{* *}}\end{array}$ & $\begin{array}{l}2.535 \\
{[29.28]^{* *}}\end{array}$ \\
\hline Marital Status (=1 if Married) & $\begin{array}{l}0.261 \\
{[2.31]^{*}}\end{array}$ & $\begin{array}{l}0.330 \\
{[3.06]^{* *}}\end{array}$ & $\begin{array}{l}0.340 \\
{[3.53]^{* *}}\end{array}$ & $\begin{array}{l}0.247 \\
{[2.61]^{* *}}\end{array}$ & $\begin{array}{l}0.470 \\
{[5.28]^{* *}}\end{array}$ & $\begin{array}{l}0.121 \\
{[1.28]}\end{array}$ & $\begin{array}{l}0.167 \\
{[1.85]+}\end{array}$ & $\begin{array}{l}0.266 \\
{[7.64]^{* *}}\end{array}$ \\
\hline Race (=1 if White) & $\begin{array}{l}0.603 \\
{[3.98]^{* *}}\end{array}$ & $\begin{array}{l}1.137 \\
{[7.47]^{* *}}\end{array}$ & $\begin{array}{l}-0.141 \\
{[-1.03]}\end{array}$ & $\begin{array}{l}0.429 \\
{[2.93]^{* *}}\end{array}$ & $\begin{array}{l}0.350 \\
{[2.57]^{*}}\end{array}$ & $\begin{array}{l}0.391 \\
{[3.07]^{* *}}\end{array}$ & $\begin{array}{l}0.397 \\
{[2.74]^{* *}}\end{array}$ & $\begin{array}{l}0.515 \\
{[10.06]^{* *}}\end{array}$ \\
\hline $\begin{array}{l}\text { Household Size } \\
\text { Province Effect }\end{array}$ & $\begin{array}{l}0.046 \\
{[1.90]+} \\
\text { Yes }\end{array}$ & $\begin{array}{l}0.031 \\
{[1.43]} \\
\text { Yes }\end{array}$ & $\begin{array}{l}0.008 \\
{[0.39]} \\
\text { Yes }\end{array}$ & $\begin{array}{l}-0.009 \\
{[-0.46]} \\
\text { Yes }\end{array}$ & $\begin{array}{l}-0.023 \\
{[-0.84]} \\
\text { Yes }\end{array}$ & $\begin{array}{l}0.038 \\
{[1.98]^{*}} \\
\text { Yes }\end{array}$ & $\begin{array}{l}0.012 \\
{[0.67]} \\
\text { Yes }\end{array}$ & $\begin{array}{l}0.012 \\
{[1.63]} \\
\text { Yes }\end{array}$ \\
\hline Time Effect & - & - & - & - & - & - & - & Yes \\
\hline Constant 1 & $\begin{array}{l}5.423 \\
{[13.01]^{* *}}\end{array}$ & $\begin{array}{l}4.342 \\
{[11.16]^{* *}}\end{array}$ & $\begin{array}{l}4.365 \\
{[12.68]^{* *}}\end{array}$ & $\begin{array}{l}4.791 \\
{[13.79]^{* *}}\end{array}$ & $\begin{array}{l}3.687 \\
{[10.56]^{* *}}\end{array}$ & $\begin{array}{l}4.741 \\
{[13.59]^{* *}}\end{array}$ & $\begin{array}{l}1.948 \\
{[5.60]^{* *}}\end{array}$ & $\begin{array}{l}4.236 \\
{[31.65]^{* *}}\end{array}$ \\
\hline Constant 2 & $\begin{array}{l}10.018 \\
{[20.93]^{* *}}\end{array}$ & $\begin{array}{l}8.105 \\
{[18.47]^{* *}}\end{array}$ & $\begin{array}{l}7.941 \\
{[21.15]^{* *}}\end{array}$ & $\begin{array}{l}8.429 \\
{[21.90]^{* *}}\end{array}$ & $\begin{array}{l}6.553 \\
{[17.64]^{* *}}\end{array}$ & $\begin{array}{l}7.706 \\
{[20.90]^{* *}}\end{array}$ & $\begin{array}{l}3.308 \\
{[9.28]^{* *}}\end{array}$ & $\begin{array}{l}7.068 \\
{[49.39]^{* *}}\end{array}$ \\
\hline Constant 3 & $\begin{array}{l}12.130 \\
{[24.54]^{* *}}\end{array}$ & $\begin{array}{l}10.702 \\
{[23.43]^{* *}}\end{array}$ & $\begin{array}{l}11.169 \\
{[28.07]^{* *}}\end{array}$ & $\begin{array}{l}11.758 \\
{[28.53]^{* *}}\end{array}$ & $\begin{array}{l}10.002 \\
{[25.34]^{* *}}\end{array}$ & $\begin{array}{l}11.270 \\
{[28.46]^{* *}}\end{array}$ & $\begin{array}{l}7.794 \\
{[20.20]^{* *}}\end{array}$ & $\begin{array}{l}10.282 \\
{[68.15]^{* *}}\end{array}$ \\
\hline$N$ & 2639 & 2603 & 3447 & 3240 & 3277 & 3281 & 3187 & 21674 \\
\hline Pseudo $R^{2}$ & 0.487 & 0.452 & 0.458 & 0.454 & 0.386 & 0.395 & 0.239 & 0.385 \\
\hline $\mathrm{BIC}$ & 3546.879 & 3682.909 & 4719.932 & 4562.567 & 5335.329 & 5378.496 & 6159.305 & $3.4 \mathrm{e}+04$ \\
\hline Chi-Square & 1364.756 & 1278.687 & 2041.537 & 1732.667 & 1762.256 & 1996.170 & 1150.283 & $1.2 \mathrm{e}+04$ \\
\hline P-Value & 0.000 & 0.000 & 0.000 & 0.000 & 0.000 & 0.000 & 0.000 & 0.000 \\
\hline
\end{tabular}

$t$ statistics in brackets ---- $+\mathrm{p}<.10,{ }^{*} \mathrm{p}<.05,{ }^{* *} \mathrm{p}<.01 ; \quad$ The reference groups for the categorical variables are as follows:

${ }^{1}$ Education (None or Primary School); ${ }^{2}$ Age (Category between 18 and 24 years); and ${ }^{3}$ Income (No Income) 
Table 2: Ordered Logit Estimation of Access to Investment and Savings Products

\begin{tabular}{|c|c|c|c|c|c|c|}
\hline \multirow{2}{*}{ Explanatory Variables } & (1) & (2) & (3) & (4) & (5) & $(8)$ \\
\hline & 2003 & 2004 & 2005 & 2006 & 2007 & pool \\
\hline $\begin{array}{l}\text { Disagree with the notion that one can live without a bank } \\
\text { account }\end{array}$ & $\begin{array}{l}0.142 \\
{[1.39]}\end{array}$ & $\begin{array}{l}0.194 \\
{[1.92]+}\end{array}$ & $\begin{array}{l}0.105 \\
{[0.90]}\end{array}$ & $\begin{array}{l}0.203 \\
{[1.78]+}\end{array}$ & $\begin{array}{l}-0.237 \\
{[-2.86]^{* *}}\end{array}$ & $\begin{array}{l}0.060 \\
{[1.53]}\end{array}$ \\
\hline Trade-off basic things in order to save & $\begin{array}{l}0.242 \\
{[2.24]^{*}}\end{array}$ & $\begin{array}{l}0.532 \\
{[4.83]^{* *}}\end{array}$ & $\begin{array}{l}0.330 \\
{[2.87]^{* *}}\end{array}$ & $\begin{array}{l}0.426 \\
{[3.67]^{* *}}\end{array}$ & $\begin{array}{l}-0.157 \\
{[-1.54]}\end{array}$ & $\begin{array}{l}0.241 \\
{[5.37]^{* *}}\end{array}$ \\
\hline Optimism & $\begin{array}{l}0.081 \\
{[2.00]^{*}}\end{array}$ & $\begin{array}{l}0.116 \\
{[2.67]^{* *}}\end{array}$ & $\begin{array}{l}-0.008 \\
{[-0.15]}\end{array}$ & $\begin{array}{l}0.036 \\
{[0.65]}\end{array}$ & $\begin{array}{l}0.069 \\
{[1.75]+}\end{array}$ & $\begin{array}{l}0.092 \\
{[4.96]^{* *}}\end{array}$ \\
\hline Physical access to formal financial institutions & $\begin{array}{l}0.089 \\
{[3.85]^{* *}}\end{array}$ & $\begin{array}{l}0.057 \\
{[2.41]^{*}}\end{array}$ & $\begin{array}{l}0.042 \\
{[1.56]}\end{array}$ & $\begin{array}{l}-0.035 \\
{[-1.23]}\end{array}$ & $\begin{array}{l}0.055 \\
{[2.99]^{* *}}\end{array}$ & $\begin{array}{l}0.051 \\
{[5.83]^{* *}}\end{array}$ \\
\hline High School $^{1}$ & $\begin{array}{l}-0.165 \\
{[-1.34]}\end{array}$ & $\begin{array}{l}-0.141 \\
{[-1.22]}\end{array}$ & $\begin{array}{l}0.261 \\
{[1.66]+}\end{array}$ & $\begin{array}{l}-0.149 \\
{[-0.99]}\end{array}$ & $\begin{array}{l}0.124 \\
{[1.00]}\end{array}$ & $\begin{array}{l}-0.019 \\
{[-0.35]}\end{array}$ \\
\hline Matriculation and Some University & $\begin{array}{l}0.256 \\
{[1.80]+}\end{array}$ & $\begin{array}{l}0.179 \\
{[1.21]}\end{array}$ & $\begin{array}{l}0.681 \\
{[3.80]^{* *}}\end{array}$ & $\begin{array}{l}-0.067 \\
{[-0.38]}\end{array}$ & $\begin{array}{l}0.070 \\
{[0.53]}\end{array}$ & $\begin{array}{l}0.152 \\
{[2.53]^{*}}\end{array}$ \\
\hline University completed and above & $\begin{array}{l}0.960 \\
{[2.86]^{* *}}\end{array}$ & $\begin{array}{l}0.913 \\
{[3.01]^{* *}}\end{array}$ & $\begin{array}{l}1.090 \\
{[3.68]^{* *}}\end{array}$ & $\begin{array}{l}0.081 \\
{[0.23]}\end{array}$ & $\begin{array}{l}0.543 \\
{[1.68]+}\end{array}$ & $\begin{array}{l}0.896 \\
{[6.66]^{* *}}\end{array}$ \\
\hline $25-29$ years $^{2}$ & $\begin{array}{l}0.565 \\
{[2.57]^{*}}\end{array}$ & $\begin{array}{l}0.610 \\
{[2.92]^{* *}}\end{array}$ & $\begin{array}{l}0.713 \\
{[3.23]^{* *}}\end{array}$ & $\begin{array}{l}0.422 \\
{[1.93]+}\end{array}$ & $\begin{array}{l}-0.244 \\
{[-1.96]^{*}}\end{array}$ & $\begin{array}{l}0.105 \\
{[1.69]+}\end{array}$ \\
\hline $30-34$ years & $\begin{array}{l}1.152 \\
{[5.64]^{* *}}\end{array}$ & $\begin{array}{l}1.166 \\
{[5.60]^{* *}}\end{array}$ & $\begin{array}{l}1.053 \\
{[4.99]^{* *}}\end{array}$ & $\begin{array}{l}0.644 \\
{[3.08]^{* *}}\end{array}$ & $\begin{array}{l}-0.209 \\
{[-1.43]}\end{array}$ & $\begin{array}{l}0.452 \\
{[6.97]^{* *}}\end{array}$ \\
\hline $35-39$ years & $\begin{array}{l}1.460 \\
{[7.15]^{* *}}\end{array}$ & $\begin{array}{l}1.183 \\
{[5.45]^{* *}}\end{array}$ & $\begin{array}{l}0.846 \\
{[3.66]^{* *}}\end{array}$ & $\begin{array}{l}0.605 \\
{[2.92]^{* *}}\end{array}$ & $\begin{array}{l}-0.357 \\
{[-2.39]^{*}}\end{array}$ & $\begin{array}{l}0.424 \\
{[6.25]^{* *}}\end{array}$ \\
\hline $40-44$ years & $\begin{array}{l}1.334 \\
{[6.06]^{* *}}\end{array}$ & $\begin{array}{l}1.496 \\
{[6.76]^{* *}}\end{array}$ & $\begin{array}{l}1.055 \\
{[4.48]^{* *}}\end{array}$ & $\begin{array}{l}0.860 \\
{[3.86]^{* *}}\end{array}$ & $\begin{array}{l}-0.653 \\
{[-3.81]^{* *}}\end{array}$ & $\begin{array}{l}0.483 \\
{[6.36]^{* *}}\end{array}$ \\
\hline $45-49$ years & $\begin{array}{l}1.639 \\
{[7.40]^{* *}}\end{array}$ & $\begin{array}{l}1.240 \\
{[5.16]^{* *}}\end{array}$ & $\begin{array}{l}1.217 \\
{[5.04]^{* *}}\end{array}$ & $\begin{array}{l}0.509 \\
{[2.07]^{*}}\end{array}$ & $\begin{array}{l}-0.708 \\
{[-3.91]^{* *}}\end{array}$ & $\begin{array}{l}0.494 \\
{[6.10]^{* *}}\end{array}$ \\
\hline $50-54$ years & $\begin{array}{l}1.483 \\
{[5.87]^{* *}}\end{array}$ & $\begin{array}{l}1.399 \\
{[5.66]^{* *}}\end{array}$ & $\begin{array}{l}1.089 \\
{[4.06]^{* *}}\end{array}$ & $\begin{array}{l}0.921 \\
{[3.52]^{* *}}\end{array}$ & $\begin{array}{l}-0.722 \\
{[-3.46]^{* *}}\end{array}$ & $\begin{array}{l}0.488 \\
{[5.24]^{* *}}\end{array}$ \\
\hline $55-59$ years & $\begin{array}{l}1.856 \\
{[7.35]^{* *}}\end{array}$ & $\begin{array}{l}1.755 \\
{[6.65]^{* *}}\end{array}$ & $\begin{array}{l}1.326 \\
{[4.84]^{* *}}\end{array}$ & $\begin{array}{l}0.975 \\
{[3.74]^{* *}}\end{array}$ & $\begin{array}{l}-0.940 \\
{[-4.50]^{* *}}\end{array}$ & $\begin{array}{l}0.649 \\
{[6.54]^{* *}}\end{array}$ \\
\hline $60-64$ years & $\begin{array}{l}1.430 \\
{[5.06]^{* *}}\end{array}$ & $\begin{array}{l}1.585 \\
{[6.64]^{* *}}\end{array}$ & $\begin{array}{l}0.960 \\
{[3.12]^{* *}}\end{array}$ & $\begin{array}{l}-0.023 \\
{[-0.06]}\end{array}$ & $\begin{array}{l}-0.707 \\
{[-3.01]^{* *}}\end{array}$ & $\begin{array}{l}0.387 \\
{[3.77]^{* *}}\end{array}$ \\
\hline $65+$ years & $\begin{array}{l}1.408 \\
{[6.15]^{* *}}\end{array}$ & $\begin{array}{l}1.449 \\
{[6.14]^{* *}}\end{array}$ & $\begin{array}{l}1.126 \\
{[4.49]^{* *}}\end{array}$ & $\begin{array}{l}0.565 \\
{[2.29]^{*}}\end{array}$ & $\begin{array}{l}-0.865 \\
{[-4.47]^{* *}}\end{array}$ & $\begin{array}{l}0.391 \\
{[4.71]^{* *}}\end{array}$ \\
\hline Below Average Income ${ }^{3}$ & $\begin{array}{l}0.770 \\
{[5.32]^{* *}}\end{array}$ & $\begin{array}{l}0.748 \\
{[5.30]^{* *}}\end{array}$ & $\begin{array}{l}0.702 \\
{[3.56]^{* *}}\end{array}$ & $\begin{array}{l}0.766 \\
{[4.61]^{* *}}\end{array}$ & $\begin{array}{l}-0.388 \\
{[-3.94]^{* *}}\end{array}$ & $\begin{array}{l}0.379 \\
{[7.97]^{* *}}\end{array}$ \\
\hline Average Income & $\begin{array}{l}1.103 \\
{[6.50]^{* *}}\end{array}$ & $\begin{array}{l}0.776 \\
{[4.50]^{* *}}\end{array}$ & $\begin{array}{l}0.873 \\
{[3.55]^{* *}}\end{array}$ & $\begin{array}{l}0.921 \\
{[4.31]^{* *}}\end{array}$ & $\begin{array}{l}-0.390 \\
{[-3.25]^{* *}}\end{array}$ & $\begin{array}{l}0.408 \\
{[6.76]^{* *}}\end{array}$ \\
\hline Above Average Income & $\begin{array}{l}1.538 \\
{[7.64]^{* *}}\end{array}$ & $\begin{array}{l}1.475 \\
{[7.34]^{* *}}\end{array}$ & $\begin{array}{l}1.037 \\
{[4.15]^{* *}}\end{array}$ & $\begin{array}{l}1.016 \\
{[4.57]^{* *}}\end{array}$ & $\begin{array}{l}0.174 \\
{[1.29]}\end{array}$ & $\begin{array}{l}0.754 \\
{[11.47]^{* *}}\end{array}$ \\
\hline High Income & $\begin{array}{l}3.308^{2} \\
{[4.20]^{* *}}\end{array}$ & $\begin{array}{l}2.831 \\
{[4.96]^{* *}}\end{array}$ & $\begin{array}{l}2.513 \\
{[6.71]^{* *}}\end{array}$ & $\begin{array}{l}1.654 \\
{[4.72]^{* *}}\end{array}$ & $\begin{array}{l}1.139 \\
{[6.10]^{* *}}\end{array}$ & $\begin{array}{l}0.876 \\
{[8.75]^{* *}}\end{array}$ \\
\hline Marital Status (=1 if Married) & $\begin{array}{l}0.246 \\
{[2.43]^{*}}\end{array}$ & $\begin{array}{l}0.314 \\
{[3.01]^{* *}}\end{array}$ & $\begin{array}{l}0.239 \\
{[2.03]^{*}}\end{array}$ & $\begin{array}{l}0.279 \\
{[2.35]^{*}}\end{array}$ & $\begin{array}{l}0.098 \\
{[1.04]}\end{array}$ & $\begin{array}{l}0.185 \\
{[4.37]^{* *}}\end{array}$ \\
\hline Race (=1 if White) & $\begin{array}{l}0.118 \\
{[0.78]}\end{array}$ & $\begin{array}{l}0.151 \\
{[0.91]}\end{array}$ & $\begin{array}{l}-0.344 \\
{[-1.93]+}\end{array}$ & $\begin{array}{l}-0.416 \\
{[-1.94]+}\end{array}$ & $\begin{array}{l}0.741 \\
{[5.68]^{* *}}\end{array}$ & $\begin{array}{l}0.188 \\
{[3.05]^{* *}}\end{array}$ \\
\hline Household Size & $\begin{array}{l}0.024 \\
{[1.04]}\end{array}$ & $\begin{array}{l}0.097 \\
{[4.80]^{* *}}\end{array}$ & $\begin{array}{l}0.076 \\
{[3.13]^{* *}}\end{array}$ & $\begin{array}{l}-0.052 \\
{[-2.06]^{*}}\end{array}$ & $\begin{array}{l}-0.048 \\
{[-1.83]+}\end{array}$ & $\begin{array}{l}0.026 \\
{[2.65]^{* *}}\end{array}$ \\
\hline Province Effect & Yes & Yes & Yes & Yes & Yes & Yes \\
\hline Time Effect & - & - & - & - & - & Yes \\
\hline Constant 1 & $\begin{array}{l}3.430 \\
{[9.34]^{* *}}\end{array}$ & $\begin{array}{l}4.204 \\
{[11.27]^{* *}}\end{array}$ & $\begin{array}{l}4.236 \\
{[9.15]^{* *}}\end{array}$ & $\begin{array}{l}3.457 \\
{[7.60]^{* *}}\end{array}$ & $\begin{array}{l}-0.749 \\
{[-2.30]^{*}}\end{array}$ & $\begin{array}{l}2.376 \\
{[15.63]^{* *}}\end{array}$ \\
\hline Constant 2 & $\begin{array}{l}4.618 \\
{[12.50]^{* *}}\end{array}$ & $\begin{array}{l}5.506 \\
{[14.48]^{* *}}\end{array}$ & $\begin{array}{l}4.973 \\
{[10.66]^{* *}}\end{array}$ & $\begin{array}{l}4.730 \\
{[10.23]^{* *}}\end{array}$ & $\begin{array}{l}3.388 \\
{[10.24]^{* *}}\end{array}$ & $\begin{array}{l}4.308 \\
{[27.60]^{* *}}\end{array}$ \\
\hline Constant 3 & $\begin{array}{l}5.927 \\
{[15.92]^{* *}}\end{array}$ & $\begin{array}{l}6.913 \\
{[17.72]^{* *}}\end{array}$ & $\begin{array}{l}6.099 \\
{[12.87]^{* *}}\end{array}$ & $\begin{array}{l}6.001 \\
{[12.58]^{* *}}\end{array}$ & $\begin{array}{l}4.797 \\
{[14.12]^{* *}}\end{array}$ & $\begin{array}{l}5.523 \\
{[34.65]^{* *}}\end{array}$ \\
\hline$N$ & 2639 & 2603 & 3447 & 3240 & 3277 & 15206 \\
\hline Pseudo $R^{2}$ & 0.146 & 0.126 & 0.087 & 0.084 & 0.080 & 0.148 \\
\hline BIC & 4653.168 & 4491.355 & 3879.334 & 3507.319 & 5342.428 & $2.4 \mathrm{e}+04$ \\
\hline Chi-Square & 563.881 & 458.122 & 312.235 & 310.239 & 415.517 & 3750.689 \\
\hline P-Value & 0.000 & 0.000 & 0.000 & 0.000 & 0.000 & 0.000 \\
\hline
\end{tabular}


Table 3: Ordered Logit Estimation of Access to Insurance and Assurance Products

\begin{tabular}{|c|c|c|c|c|c|c|c|c|}
\hline Fxnlanatory Variables & (1) & (2) & (3) & (4) & $(5)$ & (6) & $(7)$ & $(8)$ \\
\hline Explanatory V ariables & 2003 & 2004 & 2005 & 2006 & 2007 & 2008 & 2009 & pool \\
\hline $\begin{array}{l}\text { Disagree with the notion that one } \\
\text { can live without a bank acc. }\end{array}$ & $\begin{array}{l}0.480 \\
{[4.21]^{* *}}\end{array}$ & $\begin{array}{l}0.432 \\
{[3.62]^{* *}}\end{array}$ & $\begin{array}{l}0.141 \\
{[1.20]}\end{array}$ & $\begin{array}{l}0.758 \\
{[6.23]^{* *}}\end{array}$ & $\begin{array}{l}0.416 \\
{[3.87]^{* *}}\end{array}$ & $\begin{array}{l}0.477 \\
{[4.39]^{* *}}\end{array}$ & $\begin{array}{l}0.424 \\
{[3.99] * *}\end{array}$ & $\begin{array}{l}0.448 \\
{[10.72] * *}\end{array}$ \\
\hline $\begin{array}{l}\text { Trade-off basic things in order to } \\
\text { save }\end{array}$ & $\begin{array}{l}0.177 \\
{[1.50]}\end{array}$ & $\begin{array}{l}0.297 \\
{[2.41]^{*}}\end{array}$ & $\begin{array}{l}-0.008 \\
{[-0.06]}\end{array}$ & $\begin{array}{l}-0.085 \\
{[-0.72]}\end{array}$ & $\begin{array}{l}0.122 \\
{[1.14]}\end{array}$ & $\begin{array}{l}0.236 \\
{[2.28]^{*}}\end{array}$ & $\begin{array}{l}0.454 \\
{[4.08]^{* *}}\end{array}$ & $\begin{array}{l}0.178 \\
{[4.25]^{* *}}\end{array}$ \\
\hline Optimism & $\begin{array}{l}0.132 \\
{[2.52]^{*}}\end{array}$ & $\begin{array}{l}0.195 \\
{[3.44]^{* *}}\end{array}$ & $\begin{array}{l}0.096 \\
{[1.64]}\end{array}$ & $\begin{array}{l}0.148 \\
{[2.57]^{*}}\end{array}$ & $\begin{array}{l}0.242 \\
{[4.17]^{* *}}\end{array}$ & $\begin{array}{l}0.113 \\
{[2.10]^{*}}\end{array}$ & $\begin{array}{l}0.057 \\
{[1.02]}\end{array}$ & $\begin{array}{l}0.145 \\
{[6.93]^{* *}}\end{array}$ \\
\hline $\begin{array}{l}\text { Physical access to formal financial } \\
\text { institutions }\end{array}$ & $\begin{array}{l}0.284 \\
{[10.12]^{* *}}\end{array}$ & $\begin{array}{l}0.237 \\
{[7.58]^{* *}}\end{array}$ & $\begin{array}{l}0.213 \\
{[7.34]^{* *}}\end{array}$ & $\begin{array}{l}0.331 \\
{[9.85]^{* *}}\end{array}$ & $\begin{array}{l}0.292 \\
{[10.06]^{* *}}\end{array}$ & $\begin{array}{l}0.274 \\
{[8.78]^{* *}}\end{array}$ & $\begin{array}{l}0.285 \\
{[9.97]^{* *}}\end{array}$ & $\begin{array}{l}0.267 \\
{[24.08]^{* *}}\end{array}$ \\
\hline High School & $\begin{array}{l}0.148 \\
{[0.91]}\end{array}$ & $\begin{array}{l}-0.038 \\
{[-0.25]}\end{array}$ & $\begin{array}{l}0.650 \\
{[2.94]^{* *}}\end{array}$ & $\begin{array}{l}0.558 \\
{[2.80]^{* *}}\end{array}$ & $\begin{array}{l}0.289 \\
{[1.42]}\end{array}$ & $\begin{array}{l}0.053 \\
{[0.26]}\end{array}$ & $\begin{array}{l}0.528 \\
{[2.79]^{* *}}\end{array}$ & $\begin{array}{l}0.293 \\
{[4.32]^{* *}}\end{array}$ \\
\hline Matriculation and Some University & $\begin{array}{l}0.734 \\
{[4.04]^{* *}}\end{array}$ & $\begin{array}{l}0.654 \\
{[3.67]^{* *}}\end{array}$ & $\begin{array}{l}1.409 \\
{[5.91]^{* *}}\end{array}$ & $\begin{array}{l}1.192 \\
{[5.60]^{* *}}\end{array}$ & $\begin{array}{l}0.782 \\
{[3.98]^{* *}}\end{array}$ & $\begin{array}{l}0.611 \\
{[3.05]^{* *}}\end{array}$ & $\begin{array}{l}1.232 \\
{[6.56]^{* *}}\end{array}$ & $\begin{array}{l}0.945 \\
{[13.38]^{* *}}\end{array}$ \\
\hline University completed and above & $\begin{array}{l}1.628 \\
{[5.04]^{* *}}\end{array}$ & $\begin{array}{l}1.135 \\
{[3.52]^{* *}}\end{array}$ & $\begin{array}{l}1.690 \\
{[5.36]^{* *}}\end{array}$ & $\begin{array}{l}1.470 \\
{[4.77]^{* *}}\end{array}$ & $\begin{array}{l}1.074 \\
{[3.61]^{* *}}\end{array}$ & $\begin{array}{l}0.653 \\
{[2.08]^{*}}\end{array}$ & $\begin{array}{l}1.934 \\
{[7.62]^{* *}}\end{array}$ & $\begin{array}{l}1.392 \\
{[13.15]^{* *}}\end{array}$ \\
\hline $25-29$ years & $\begin{array}{l}0.950 \\
{[3.80]^{* *}}\end{array}$ & $\begin{array}{l}0.512 \\
{[1.84]+}\end{array}$ & $\begin{array}{l}0.710 \\
{[2.92]^{* *}}\end{array}$ & $\begin{array}{l}0.788 \\
{[3.18]^{* *}}\end{array}$ & $\begin{array}{l}0.599 \\
{[3.04]^{* *}}\end{array}$ & $\begin{array}{l}0.886 \\
{[4.81]^{* *}}\end{array}$ & $\begin{array}{l}0.477 \\
{[2.25]^{*}}\end{array}$ & $\begin{array}{l}0.692 \\
{[8.26]^{* *}}\end{array}$ \\
\hline $30-34$ years & $\begin{array}{l}1.116 \\
{[4.59]^{* *}}\end{array}$ & $\begin{array}{l}0.943 \\
{[3.74]^{* *}}\end{array}$ & $\begin{array}{l}1.171 \\
{[4.72]^{* *}}\end{array}$ & $\begin{array}{l}1.056 \\
{[4.36]^{* *}}\end{array}$ & $\begin{array}{l}1.089 \\
{[5.29]^{* *}}\end{array}$ & $\begin{array}{l}1.032 \\
{[5.46]^{* *}}\end{array}$ & $\begin{array}{l}0.687 \\
{[3.17]^{* *}}\end{array}$ & {$[11.98]^{* *}$} \\
\hline $35-39$ years & $\begin{array}{l}1.587 \\
{[6.77]^{* *}}\end{array}$ & $\begin{array}{l}1.184 \\
{[4.74]^{* *}}\end{array}$ & $\begin{array}{l}1.339 \\
{[5.51]^{* *}}\end{array}$ & $\begin{array}{l}1.251 \\
{[5.17]^{* *}}\end{array}$ & $\begin{array}{l}1.156 \\
{[5.81]^{* *}}\end{array}$ & $\begin{array}{l}1.187 \\
{[6.43]^{* *}}\end{array}$ & $\begin{array}{l}1.002 \\
{[4.89]^{* *}}\end{array}$ & $\begin{array}{l}1.230 \\
{[15.14]^{* *}}\end{array}$ \\
\hline $40-44$ years & $\begin{array}{l}1.344 \\
{[5.39]^{* *}}\end{array}$ & $\begin{array}{l}1.461 \\
{[5.51]^{* *}}\end{array}$ & $\begin{array}{l}1.668 \\
{[6.41]^{* *}}\end{array}$ & $\begin{array}{l}1.029 \\
{[3.95]^{* *}}\end{array}$ & $\begin{array}{l}1.373 \\
{[6.64]^{* *}}\end{array}$ & $\begin{array}{l}1.469 \\
{[7.40]^{* *}}\end{array}$ & $\begin{array}{l}0.855 \\
{[4.02]^{* *}}\end{array}$ & $\begin{array}{l}1.326 \\
{[15.33]^{* *}}\end{array}$ \\
\hline $45-49$ years & $\begin{array}{l}2.093 \\
{[8.08]^{* *}}\end{array}$ & $\begin{array}{l}1.445 \\
{[5.25]^{* *}}\end{array}$ & $\begin{array}{l}1.562 \\
{[5.94]^{* *}}\end{array}$ & $\begin{array}{l}1.268 \\
{[4.82]^{* *}}\end{array}$ & $\begin{array}{l}1.213 \\
{[5.60]^{* *}}\end{array}$ & $\begin{array}{l}1.094 \\
{[5.27]^{* *}}\end{array}$ & $\begin{array}{l}1.161 \\
{[5.15]^{* *}}\end{array}$ & $\begin{array}{l}1.391 \\
{[15.48]^{* *}}\end{array}$ \\
\hline $50-54$ years & $\begin{array}{l}2.031 \\
{[7.22]^{* *}}\end{array}$ & $\begin{array}{l}1.614 \\
{[5.59]^{* *}}\end{array}$ & $\begin{array}{l}1.544 \\
{[5.05]^{* *}}\end{array}$ & $\begin{array}{l}1.475 \\
{[5.06]^{* *}}\end{array}$ & $\begin{array}{l}1.468 \\
{[6.05]^{* *}}\end{array}$ & $\begin{array}{l}1.387 \\
{[5.31]^{* *}}\end{array}$ & $\begin{array}{l}1.117 \\
{[4.65]^{* *}}\end{array}$ & $\begin{array}{l}1.491 \\
{[15.00]^{* *}}\end{array}$ \\
\hline $55-59$ years & $\begin{array}{l}1.439 \\
{[4.60]^{* *}}\end{array}$ & $\begin{array}{l}2.144 \\
{[6.83]^{* *}}\end{array}$ & $\begin{array}{l}1.917 \\
{[6.75]^{* *}}\end{array}$ & $\begin{array}{l}1.571 \\
{[5.51]^{* *}}\end{array}$ & $\begin{array}{l}0.884 \\
{[3.09]^{* *}}\end{array}$ & $\begin{array}{l}1.229 \\
{[4.69]^{* *}}\end{array}$ & $\begin{array}{l}1.435 \\
{[5.60]^{* *}}\end{array}$ & $\begin{array}{l}1.508 \\
{[14.25]^{* *}}\end{array}$ \\
\hline $60-64$ years & $\begin{array}{l}1.926 \\
{[5.34]^{* *}}\end{array}$ & $\begin{array}{l}1.795 \\
{[6.09]^{* *}}\end{array}$ & $\begin{array}{l}1.626 \\
{[4.87]^{* *}}\end{array}$ & $\begin{array}{l}1.859 \\
{[5.62]^{* *}}\end{array}$ & $\begin{array}{l}1.728 \\
{[6.19]^{* *}}\end{array}$ & $\begin{array}{l}1.580 \\
{[5.22]^{* *}}\end{array}$ & $\begin{array}{l}1.532 \\
{[5.56]^{* *}}\end{array}$ & $\begin{array}{l}1.717 \\
{[15.31]^{* *}}\end{array}$ \\
\hline $65+$ years & $\begin{array}{l}2.056 \\
{[7.61]^{* *}}\end{array}$ & $\begin{array}{l}1.814 \\
{[6.76]^{* *}}\end{array}$ & $\begin{array}{l}1.856 \\
{[6.85]^{* *}}\end{array}$ & $\begin{array}{l}1.508 \\
{[5.05]^{* *}}\end{array}$ & $\begin{array}{l}1.460 \\
{[5.60]^{* *}}\end{array}$ & $\begin{array}{l}1.094 \\
{[4.18]^{* *}}\end{array}$ & $\begin{array}{l}1.124 \\
{[4.63]^{* *}}\end{array}$ & $\begin{array}{l}1.553 \\
{[16.22]^{* *}}\end{array}$ \\
\hline Below Average Income & $\begin{array}{l}-0.162 \\
{[-0.82]}\end{array}$ & $\begin{array}{l}0.072 \\
{[0.36]}\end{array}$ & $\begin{array}{l}-0.193 \\
{[-0.94]}\end{array}$ & $\begin{array}{l}-0.234 \\
{[-1.08]}\end{array}$ & $\begin{array}{l}-0.491 \\
{[-2.12]^{*}}\end{array}$ & $\begin{array}{l}0.168 \\
{[0.66]}\end{array}$ & $\begin{array}{l}-0.751 \\
{[-2.80]^{* *}}\end{array}$ & $\begin{array}{l}-0.265 \\
{[-3.31]^{* *}}\end{array}$ \\
\hline Average Income & $\begin{array}{l}0.915 \\
{[4.44]^{* *}}\end{array}$ & $\begin{array}{l}1.038 \\
{[4.90]^{* *}}\end{array}$ & $\begin{array}{l}0.899 \\
{[4.04]^{* *}}\end{array}$ & $\begin{array}{l}0.812 \\
{[3.65]^{* *}}\end{array}$ & $\begin{array}{l}0.145 \\
{[0.70]}\end{array}$ & $\begin{array}{l}0.378 \\
{[1.58]}\end{array}$ & $\begin{array}{l}0.410 \\
{[1.94]+}\end{array}$ & $\begin{array}{l}0.631 \\
{[7.84]^{* *}}\end{array}$ \\
\hline Above Average Income & $\begin{array}{l}2.128 \\
{[9.06]^{* *}}\end{array}$ & $\begin{array}{l}2.267 \\
{[9.84]^{* *}}\end{array}$ & $\begin{array}{l}1.913 \\
{[8.95]^{* *}}\end{array}$ & $\begin{array}{l}1.881 \\
{[8.37]^{* *}}\end{array}$ & $\begin{array}{l}1.221 \\
{[6.42]^{* *}}\end{array}$ & $\begin{array}{l}1.424 \\
{[6.66]^{* *}}\end{array}$ & $\begin{array}{l}1.357 \\
{[6.93]^{* *}}\end{array}$ & $\begin{array}{l}1.719 \\
{[21.25]^{* *}}\end{array}$ \\
\hline High Income & $\begin{array}{l}2.439 \\
{[3.06]^{* *}}\end{array}$ & $\begin{array}{l}17.986 \\
{[31.59]^{* *}}\end{array}$ & $\begin{array}{l}3.007 \\
{[8.36]^{* *}}\end{array}$ & $\begin{array}{l}2.917 \\
{[9.45]^{* *}}\end{array}$ & $\begin{array}{l}2.488 \\
{[11.52]^{* *}}\end{array}$ & $\begin{array}{l}2.894 \\
{[12.11]^{* *}}\end{array}$ & $\begin{array}{l}2.736 \\
{[11.56]^{* *}}\end{array}$ & $\begin{array}{l}2.929 \\
{[28.82]^{* *}}\end{array}$ \\
\hline Marital Status (=1 if Married) & $\begin{array}{l}0.341 \\
{[2.91]^{* *}}\end{array}$ & $\begin{array}{l}0.301 \\
{[2.46]^{*}}\end{array}$ & $\begin{array}{l}0.305 \\
{[2.46]^{*}}\end{array}$ & $\begin{array}{l}0.629 \\
{[5.36]^{* *}}\end{array}$ & $\begin{array}{l}0.377 \\
{[3.55]^{* *}}\end{array}$ & $\begin{array}{l}0.539 \\
{[5.14]^{* *}}\end{array}$ & $\begin{array}{l}0.498 \\
{[4.52]^{* *}}\end{array}$ & $\begin{array}{l}0.421 \\
{[10.02]^{* *}}\end{array}$ \\
\hline Race (=1 if White) & $\begin{array}{l}1.206 \\
{[7.75]^{* *}}\end{array}$ & $\begin{array}{l}1.457 \\
{[9.04]^{* *}}\end{array}$ & $\begin{array}{l}0.999 \\
{[6.88]^{* *}}\end{array}$ & $\begin{array}{l}1.170 \\
{[7.14]^{* *}}\end{array}$ & $\begin{array}{l}1.177 \\
{[7.91]^{* *}}\end{array}$ & $\begin{array}{l}0.829 \\
{[6.17]^{* *}}\end{array}$ & $\begin{array}{l}1.163 \\
{[7.63]^{* *}}\end{array}$ & $\begin{array}{l}1.120 \\
{[20.15]^{* *}}\end{array}$ \\
\hline Household Size & $\begin{array}{l}0.006 \\
{[0.22]}\end{array}$ & $\begin{array}{l}-0.065 \\
{[-2.22]^{*}}\end{array}$ & $\begin{array}{l}-0.038 \\
{[-1.17]}\end{array}$ & $\begin{array}{l}0.024 \\
{[0.84]}\end{array}$ & $\begin{array}{l}0.008 \\
{[0.23]}\end{array}$ & $\begin{array}{l}0.020 \\
{[0.84]}\end{array}$ & $\begin{array}{l}0.028 \\
{[1.11]}\end{array}$ & $\begin{array}{l}-0.002 \\
{[-0.24]}\end{array}$ \\
\hline $\begin{array}{l}\text { Province Effect } \\
\text { Time Effect }\end{array}$ & Yes & $\begin{array}{l}\text { Yes } \\
-\end{array}$ & Yes & $\begin{array}{l}\text { Yes } \\
-\end{array}$ & $\begin{array}{l}\text { Yes } \\
-\end{array}$ & $\begin{array}{l}\text { Yes } \\
-\end{array}$ & $\begin{array}{l}\text { Yes } \\
-\end{array}$ & $\begin{array}{l}\text { Yes } \\
\text { Yes }\end{array}$ \\
\hline Constant 1 & $\begin{array}{l}5.480 \\
{[11.51]^{* *}}\end{array}$ & $\begin{array}{l}5.321 \\
{[11.10]^{* *}}\end{array}$ & $\begin{array}{l}5.407 \\
{[10.41]^{* *}}\end{array}$ & $\begin{array}{l}6.886 \\
{[13.80]^{* *}}\end{array}$ & $\begin{array}{l}6.875 \\
{[13.25]^{* *}}\end{array}$ & $\begin{array}{l}6.382 \\
{[13.28]^{* *}}\end{array}$ & $\begin{array}{l}6.159 \\
{[12.70]^{* *}}\end{array}$ & $\begin{array}{l}5.264 \\
{[28.31]^{* *}}\end{array}$ \\
\hline Constant 2 & $\begin{array}{l}6.235 \\
{[12.95]^{* *}}\end{array}$ & $\begin{array}{l}6.309 \\
{[13.10]^{* *}}\end{array}$ & $\begin{array}{l}5.689 \\
{[10.96]^{* *}}\end{array}$ & $\begin{array}{l}7.509 \\
{[14.94]^{* *}}\end{array}$ & $\begin{array}{l}7.548 \\
{[14.37]^{* *}}\end{array}$ & $\begin{array}{l}6.932 \\
{[14.33]^{* *}}\end{array}$ & $\begin{array}{l}6.903 \\
{[14.04]^{* *}}\end{array}$ & $\begin{array}{l}5.896 \\
{[31.54]^{* *}}\end{array}$ \\
\hline Constant 3 & $\begin{array}{l}7.828 \\
{[15.77]^{* *}}\end{array}$ & $\begin{array}{l}7.935 \\
{[15.81]^{* *}}\end{array}$ & $\begin{array}{l}7.341 \\
{[13.92]^{* *}}\end{array}$ & $\begin{array}{l}9.310 \\
{[17.93]^{* *}}\end{array}$ & $\begin{array}{l}9.336 \\
{[17.30]^{* *}}\end{array}$ & $\begin{array}{l}8.766 \\
{[17.75]^{* *}}\end{array}$ & $\begin{array}{l}8.796 \\
{[17.61]^{* *}}\end{array}$ & $\begin{array}{l}7.597 \\
{[39.76]^{* *}}\end{array}$ \\
\hline $\begin{array}{l}N \\
\text { Pseudo } R^{2}\end{array}$ & $\begin{array}{l}2639 \\
0.372\end{array}$ & $\begin{array}{l}2603 \\
0.362\end{array}$ & $\begin{array}{l}3447 \\
0.369\end{array}$ & $\begin{array}{l}3240 \\
0.396\end{array}$ & $\begin{array}{l}3277 \\
0.327\end{array}$ & $\begin{array}{l}3281 \\
0.317\end{array}$ & $\begin{array}{l}3187 \\
0.356\end{array}$ & $\begin{array}{l}21674 \\
0.346\end{array}$ \\
\hline $\mathrm{BIC}$ & 3503.368 & 3296.698 & 3500.759 & 3356.285 & 4118.061 & 4281.397 & 4112.051 & $2.5 e+04$ \\
\hline Chi-Square & 1158.892 & 2042.075 & 1178.789 & 1186.667 & 1224.885 & 1194.349 & 1341.180 & 8008.472 \\
\hline P-Value & 0.000 & 0.000 & 0.000 & 0.000 & 0.000 & 0.000 & 0.000 & 0.000 \\
\hline
\end{tabular}


Table 4: Marginal Effects post Generalized Ordered Probit Estimation Case of Access to General Accounts and Services

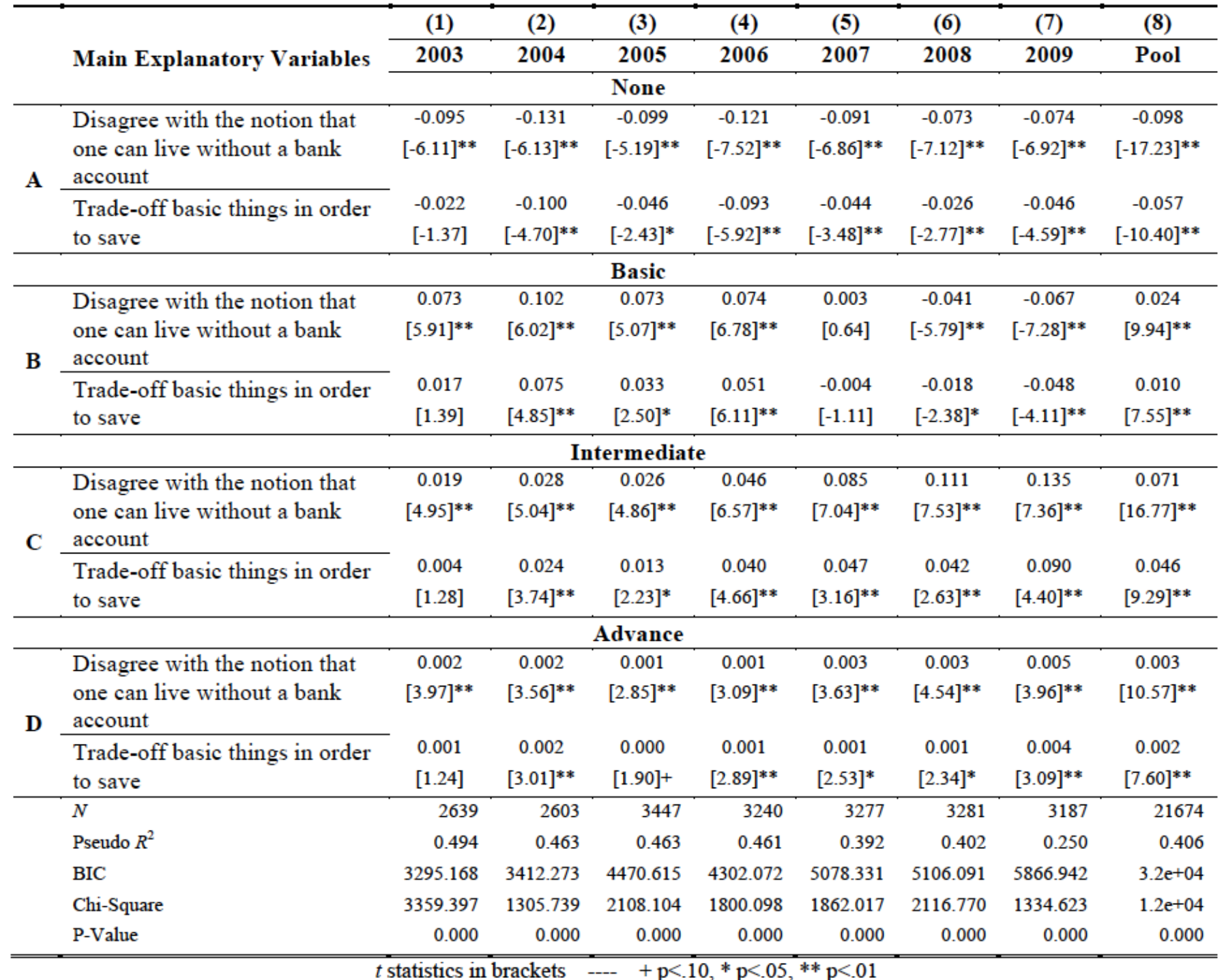


Table 5: Marginal Effects post Generalized Ordered Probit Estimation

Case of Investment/Savings Products

\begin{tabular}{|c|c|c|c|c|c|c|c|}
\hline & \multirow{2}{*}{ Main Explanatory Variables } & (1) & $(2)$ & (3) & (4) & $(\mathbf{5})$ & (6) \\
\hline & & 2003 & 2004 & 2005 & 2006 & 2007 & Pool \\
\hline \multicolumn{8}{|c|}{ None } \\
\hline \multirow{4}{*}{$\mathbf{A}$} & Disagree with the notion that one & -0.029 & -0.039 & -0.008 & -0.022 & 0.036 & -0.012 \\
\hline & can live without a bank account & {$[-1.43]$} & {$[-1.94]+$} & {$[-0.95]$} & {$[-1.86]+$} & {$[2.77]^{* *} *$} & {$[-1.29]$} \\
\hline & Trade-off basic things in order to & -0.047 & -0.117 & -0.021 & -0.048 & 0.023 & -0.052 \\
\hline & save & {$[-2.12]^{*}$} & {$[-4.91]^{* *}$} & {$[-2.36]^{*}$} & {$[-3.41]^{* k}$} & {$[1.44]$} & {$[-4.91]^{* *}$} \\
\hline & Basic & & & & & & \\
\hline \multirow{4}{*}{ B } & Disagree with the notion that one & 0.017 & 0.025 & 0.001 & 0.017 & -0.026 & 0.009 \\
\hline & can live without a bank account & {$[1.43]$} & {$[1.94]+$} & {$[0.76]$} & {$[1.86]+$} & {$[-2.74]^{* *}$} & [1.29] \\
\hline & Trade-off basic things in order to & 0.027 & 0.074 & 0.002 & 0.036 & -0.017 & 0.038 \\
\hline & save & {$[2.16]^{*}$} & {$[4.96]^{* *}$} & {$[1.01]$} & {$[3.36]^{* *}$} & {$[-1.41]$} & {$[4.96]^{* *}$} \\
\hline & Intermediate & & & & & & \\
\hline \multirow{4}{*}{$\mathrm{C}$} & Disagree with the notion that one & 0.010 & 0.011 & 0.006 & 0.005 & -0.009 & 0.003 \\
\hline & can live without a bank account & {$[1.42]$} & {$[1.89]+$} & {$[0.94]$} & {$[1.83]+$} & {$[-2.67]^{* *}$} & [1.29] \\
\hline & Trade-off basic things in order to & 0.016 & 0.037 & 0.016 & 0.011 & -0.005 & 0.011 \\
\hline & save & {$[2.03]^{*}$} & {$[4.34]^{* *}$} & {$[2.32]^{*}$} & {$[3.23]^{* *}$} & {$[-1.53]$} & {$[4.69]^{* *}$} \\
\hline \multirow{10}{*}{$\mathbf{D}$} & Advance & & & & & & \\
\hline & Disagree with the notion that one & 0.003 & 0.002 & 0.001 & 0.001 & -0.002 & 0.001 \\
\hline & can live without a bank account & {$[1.38]$} & {$[1.78]+$} & {$[0.93]$} & [1.49] & {$[-2.21]^{*}$} & {$[1.28]$} \\
\hline & Trade-off basic things in order to & 0.004 & 0.007 & 0.004 & 0.001 & -0.001 & 0.003 \\
\hline & save & {$[1.95]^{+}$} & {$[3.20]^{* *}$} & {$[2.15]^{*}$} & {$[2.09]^{*}$} & {$[-1.43]$} & {$[4.38]^{* *}$} \\
\hline & $N$ & 2639 & 2603 & 3447 & 3240 & 3277 & 15206 \\
\hline & Pseudo $R^{2}$ & 0.176 & 0.166 & 0.166 & 0.139 & 0.132 & 0.247 \\
\hline & $\mathrm{BIC}$ & 4292.637 & 4094.510 & 3355.412 & 3101.695 & 4846.600 & $2.1 \mathrm{e}+04$ \\
\hline & Chi-Squares & 763.711 & 686.112 & $2.5 e+04$ & 2974.323 & 612.975 & 4634.575 \\
\hline & P-Value & 0.000 & 0.000 & 0.000 & 0.000 & 0.000 & 0.000 \\
\hline
\end{tabular}


Table 6: Marginal Effects post Generalized Ordered Probit Estimation Case of Insurance/Assurance Products

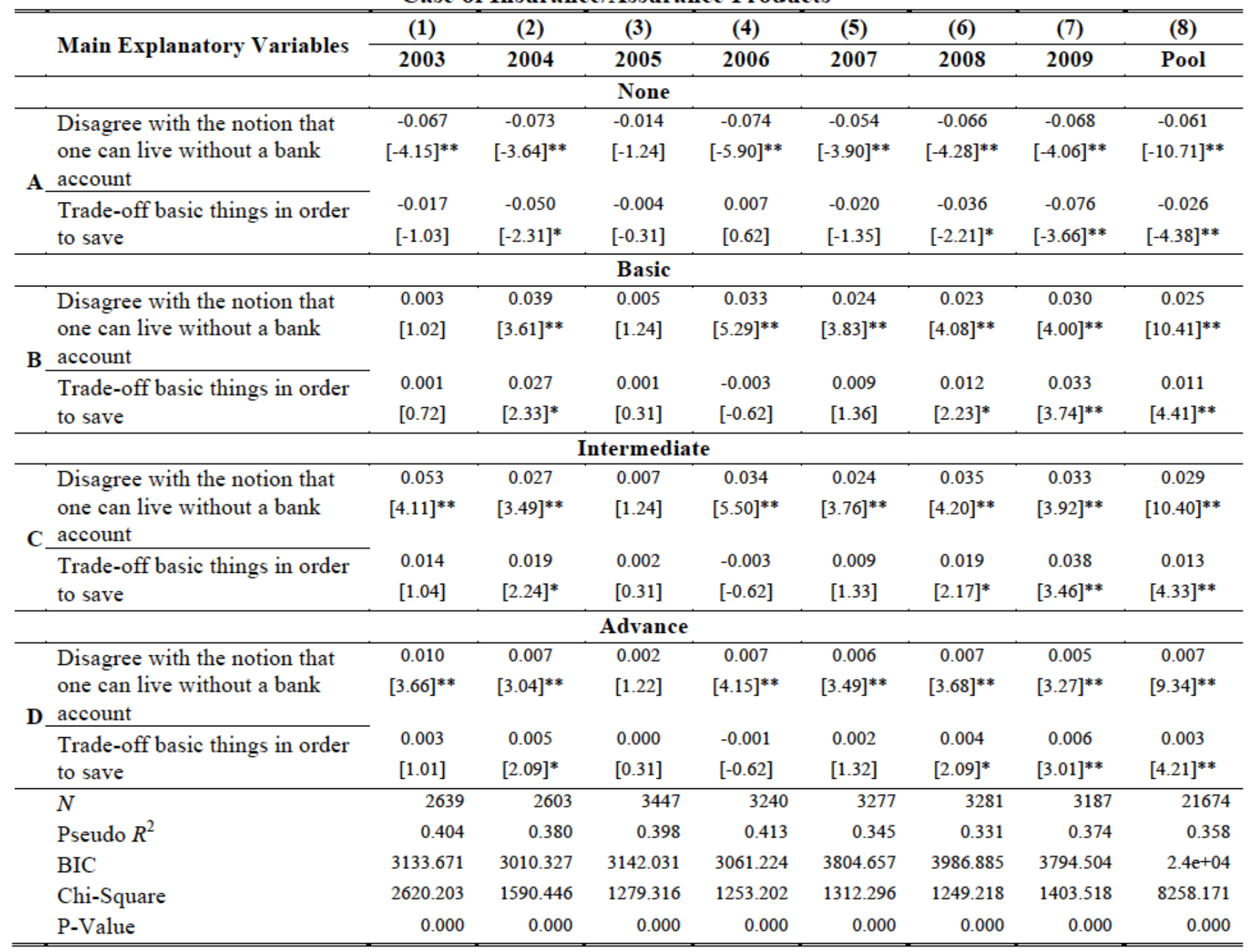


Table 7 - Pseudo Panel Results for all three type of Financial Services

\begin{tabular}{|c|c|c|c|c|c|c|}
\hline \multirow{3}{*}{ Explanatory Variables } & $(1)$ & $(2)$ & (3) & (4) & (5) & (6) \\
\hline & \multicolumn{2}{|c|}{ General Accounts and Services } & \multicolumn{2}{|c|}{ Investment/Savings Products } & \multicolumn{2}{|c|}{ Insurance/Assurance Products } \\
\hline & $\begin{array}{l}\text { Fixed } \\
\text { Effects }\end{array}$ & Random Effects & $\begin{array}{l}\text { Fixed } \\
\text { Effects }\end{array}$ & Random Effects & $\begin{array}{c}\text { Fixed } \\
\text { Effects }\end{array}$ & Random Effects \\
\hline $\begin{array}{l}\text { Disagree with the notion that } \\
\text { one can live without a bank } \\
\text { account }\end{array}$ & $\begin{array}{c}0.108 \\
{[1.89]+}\end{array}$ & $\begin{array}{c}0.135 \\
{[2.49]^{*}}\end{array}$ & $\begin{array}{l}-0.073 \\
{[-0.62]}\end{array}$ & $\begin{array}{l}-0.011 \\
{[-0.10]}\end{array}$ & $\begin{array}{c}0.133 \\
{[1.81]+}\end{array}$ & $\begin{array}{l}0.043 \\
{[0.58]}\end{array}$ \\
\hline $\begin{array}{l}\text { Trade-off basic things in } \\
\text { order to save }\end{array}$ & $\begin{array}{c}0.169 \\
{[2.66]^{* *}}\end{array}$ & $\begin{array}{l}0.059 \\
{[1.00]}\end{array}$ & $\begin{array}{c}-0.238 \\
{[-1.88]+}\end{array}$ & $\begin{array}{c}-0.211 \\
{[-1.93]+}\end{array}$ & $\begin{array}{l}-0.015 \\
{[-0.19]}\end{array}$ & $\begin{array}{l}-0.119 \\
{[-1.47]}\end{array}$ \\
\hline $\begin{array}{l}\text { Physical access to formal } \\
\text { financial institutions }\end{array}$ & $\begin{array}{c}0.191 \\
{[13.46]^{* *}}\end{array}$ & $\begin{array}{c}0.213 \\
{[17.72]^{* *}}\end{array}$ & $\begin{array}{l}0.044 \\
{[1.60]}\end{array}$ & $\begin{array}{c}0.053 \\
{[2.48]^{*}}\end{array}$ & $\begin{array}{c}0.072 \\
{[3.93]^{* *}}\end{array}$ & $\begin{array}{c}0.130 \\
{[7.80]^{* *}}\end{array}$ \\
\hline Optimism & $\begin{array}{c}0.066 \\
{[2.69]^{* *}}\end{array}$ & $\begin{array}{c}0.041 \\
{[1.84]+}\end{array}$ & $\begin{array}{l}0.019 \\
{[0.37]}\end{array}$ & $\begin{array}{l}-0.006 \\
{[-0.14]}\end{array}$ & $\begin{array}{l}0.045 \\
{[1.43]}\end{array}$ & $\begin{array}{l}0.024 \\
{[0.80]}\end{array}$ \\
\hline Education & $\begin{array}{c}0.159 \\
{[4.14]^{* *}}\end{array}$ & $\begin{array}{c}0.140 \\
{[5.48]^{* *}}\end{array}$ & $\begin{array}{l}0.049 \\
{[0.59]}\end{array}$ & $\begin{array}{l}0.058 \\
{[1.21]}\end{array}$ & $\begin{array}{c}0.343 \\
{[6.90]^{* *}}\end{array}$ & $\begin{array}{c}0.127 \\
{[3.49]^{* *}}\end{array}$ \\
\hline Income & $\begin{array}{c}0.109 \\
{[4.63]^{* *}}\end{array}$ & $\begin{array}{c}0.161 \\
{[7.54]^{* *}}\end{array}$ & $\begin{array}{c}0.101 \\
{[1.95]+}\end{array}$ & $\begin{array}{c}0.164 \\
{[3.79]^{* *}}\end{array}$ & $\begin{array}{c}0.211 \\
{[6.94]^{* * *}}\end{array}$ & $\begin{array}{c}0.263 \\
{[9.07]^{* *}}\end{array}$ \\
\hline Married & $\begin{array}{l}-0.009 \\
{[-0.14]}\end{array}$ & $\begin{array}{c}0.238 \\
{[6.52]^{* *}}\end{array}$ & $\begin{array}{l}-0.074 \\
{[-0.57]}\end{array}$ & $\begin{array}{c}0.214 \\
{[3.36]^{* *}}\end{array}$ & $\begin{array}{c}0.143 \\
{[1.80]+}\end{array}$ & $\begin{array}{c}0.429 \\
{[8.13]^{* * *}}\end{array}$ \\
\hline Race (White) & $\begin{array}{c}0.235 \\
{[2.95]^{* *}}\end{array}$ & $\begin{array}{c}0.083 \\
{[1.33]}\end{array}$ & $\begin{array}{c}0.173 \\
{[1.07]}\end{array}$ & $\begin{array}{c}0.173 \\
{[1.54]}\end{array}$ & $\begin{array}{c}0.688 \\
{[6.69]^{* *}}\end{array}$ & $\begin{array}{c}0.701 \\
{[8.02]^{* *}}\end{array}$ \\
\hline Household Size & $\begin{array}{l}-0.002 \\
{[-0.15]}\end{array}$ & $\begin{array}{c}0.002 \\
{[0.18]}\end{array}$ & $\begin{array}{c}0.005 \\
{[0.18]}\end{array}$ & $\begin{array}{c}0.039 \\
{[1.77]+}\end{array}$ & $\begin{array}{c}0.006 \\
{[0.30]}\end{array}$ & $\begin{array}{c}0.002 \\
{[0.10]}\end{array}$ \\
\hline 2004 Year Dummy & $\begin{array}{c}-0.974 \\
{[-49.41]^{* *}}\end{array}$ & $\begin{array}{c}-0.970 \\
{[-47.46]^{* *}}\end{array}$ & $\begin{array}{c}-0.069 \\
{[-2.12]^{*}}\end{array}$ & $\begin{array}{c}-0.060 \\
{[-1.85]+}\end{array}$ & $\begin{array}{c}-0.056 \\
{[-2.19]^{*}}\end{array}$ & $\begin{array}{c}-0.054 \\
{[-1.99]^{*}}\end{array}$ \\
\hline 2005 Year Dummy & $\begin{array}{c}-1.000 \\
{[-50.25]^{* *}}\end{array}$ & $\begin{array}{c}-0.996 \\
{[-48.65]^{* *}}\end{array}$ & $\begin{array}{c}-0.373 \\
{[-11.28]^{* *}}\end{array}$ & $\begin{array}{c}-0.370 \\
{[-11.27]^{* *}}\end{array}$ & $\begin{array}{c}-0.176 \\
{[-6.86]^{* *}}\end{array}$ & $\begin{array}{c}-0.153 \\
{[-5.67]^{*} * *}\end{array}$ \\
\hline 2006 Year Dummy & $\begin{array}{c}-1.026 \\
{[-47.92]^{* *}}\end{array}$ & $\begin{array}{c}-1.031 \\
{[-47.52]^{* *}}\end{array}$ & $\begin{array}{c}-0.449 \\
{[-12.27]^{* *}}\end{array}$ & $\begin{array}{c}-0.442 \\
{[-12.46]^{* *}}\end{array}$ & $\begin{array}{c}-0.192 \\
{[-6.95]^{* *}}\end{array}$ & $\begin{array}{c}-0.192 \\
{[-6.69]^{* *}}\end{array}$ \\
\hline 2007 Year Dummy & $\begin{array}{c}-0.991 \\
{[-30.68]^{* *}}\end{array}$ & $\begin{array}{c}-1.014 \\
{[-33.47]^{* *}}\end{array}$ & $\begin{array}{c}0.153 \\
{[2.47]^{*}}\end{array}$ & $\begin{array}{c}0.166 \\
{[3.05]^{* *}}\end{array}$ & $\begin{array}{c}-0.327 \\
{[-7.85]^{*} *}\end{array}$ & $\begin{array}{c}-0.316 \\
{[-7.69]^{*} *}\end{array}$ \\
\hline 2008 Year Dummy & $\begin{array}{c}-1.007 \\
{[-33.93]^{* *}}\end{array}$ & $\begin{array}{c}-1.024 \\
{[-36.64]^{* *}}\end{array}$ & - & - & $\begin{array}{c}-0.397 \\
{[-10.36]^{* *}}\end{array}$ & $\begin{array}{c}-0.367 \\
{[-9.75]^{* *}}\end{array}$ \\
\hline 2009 Year Dummy & $\begin{array}{c}-0.781 \\
{[-26.39]^{* *}}\end{array}$ & $\begin{array}{c}-0.799 \\
{[-29.11]^{* *}}\end{array}$ & $\begin{array}{l}- \\
-\end{array}$ & $\begin{array}{l}- \\
-\end{array}$ & $\begin{array}{c}-0.326 \\
{[-8.54]^{* *}}\end{array}$ & $\begin{array}{c}-0.291 \\
{[-7.86]^{* *}}\end{array}$ \\
\hline Constant & $\begin{array}{l}0.001 \\
{[0.01]}\end{array}$ & $\begin{array}{l}-0.116 \\
{[-0.78]}\end{array}$ & $\begin{array}{c}0.111 \\
{[0.33]}\end{array}$ & $\begin{array}{l}-0.267 \\
{[-0.96]}\end{array}$ & $\begin{array}{c}-1.286 \\
{[-5.87]^{* *}}\end{array}$ & $\begin{array}{c}-1.142 \\
{[-5.58]^{*} *}\end{array}$ \\
\hline$N$ & 630 & 630 & 450 & 450 & 630 & 630 \\
\hline $\begin{array}{l}\text { F-Statistics (Cohort } \\
\text { Effect) }\end{array}$ & $1.87(0.00)$ & - & $1.16(0.17)$ & - & $3.03(0.00)$ & - \\
\hline Hausman Test & \multicolumn{2}{|c|}{$102.04(0.00)$} & \multicolumn{2}{|c|}{$27.67(0.01)$} & \multicolumn{2}{|c|}{$406.74(0.00)$} \\
\hline Theta & - & 0.871 & - & 0.00 & - & 0.26 \\
\hline Correlation $\left(\mathrm{U}_{\mathrm{i}}, \mathrm{Xb}\right)$ & 0.20 & - & 0.07 & - & 0.27 & - \\
\hline $\begin{array}{l}\text { F-Statistics/Wald } \\
\text { Chi-Sq. }\end{array}$ & $339.38^{* *}$ & $6073.59 * *$ & $48.93^{* *}$ & $753.26^{* * *}$ & $48.72^{* *}$ & $1453.04^{* * *}$ \\
\hline
\end{tabular}




\section{Appendices}

Appendix 1-Classifications and Trends of Access to and Use General Accounts and Services Financial Products

\begin{tabular}{|c|c|c|c|c|c|c|c|c|c|c|}
\hline \multirow{2}{*}{ No. } & \multirow{2}{*}{ Variables } & \multicolumn{2}{|c|}{ Codes } & \multicolumn{7}{|c|}{ Proportion of Access to General Accounts and Services } \\
\hline & & Old & New & 2003 & 2004 & 2005 & 2006 & 2007 & 2008 & 2009 \\
\hline 1 & Mzansi & - & 1 & - & . & 0.014 & 0.048 & 0.085 & 0.094 & 0.105 \\
\hline 2 & ATM & 3 & 1 & 0.534 & 0.498 & 0.503 & 0.566 & 0.619 & 0.642 & 0.616 \\
\hline 3 & Debit Card & 5 & 2 & 0.092 & 0.164 & 0.183 & 0.203 & 0.294 & 0.335 & 0.383 \\
\hline 4 & Savings Book & 3 & 1 & 0.054 & 0.054 & 0.036 & 0.037 & 0.036 & 0.033 & 0.038 \\
\hline 5 & Post Office Account & 3 & 1 & 0.048 & 0.045 & 0.037 & 0.035 & 0.013 & 0.009 & 0.029 \\
\hline 6 & Savings and Transaction Account & 3 & 1 & 0.429 & 0.42 & 0.371 & 0.457 & 0.488 & 0.438 & 0.421 \\
\hline 7 & Current or Cheque Accounts & 6 & 2 & 0.134 & 0.117 & 0.12 & 0.116 & 0.123 & 0.128 & 0.14 \\
\hline 8 & Credit Card & 5 & 2 & 0.092 & 0.095 & 0.093 & 0.113 & 0.121 & 0.127 & 0.113 \\
\hline 9 & Garage and Petrol Card & 7 & 3 & 0.048 & 0.047 & 0.036 & 0.034 & 0.04 & 0.043 & 0.031 \\
\hline 10 & Fixed Deposit & 6 & 2 & 0.051 & 0.071 & 0.048 & 0.046 & 0.045 & 0.063 & 0.071 \\
\hline 11 & Money Market & 7 & 3 & 0.017 & 0.024 & 0.011 & 0.014 & 0.01 & 0.021 & 0.016 \\
\hline 12 & Mortgage & 6 & 2 & 0.087 & 0.084 & 0.081 & 0.099 & 0.081 & 0.073 & 0.073 \\
\hline 13 & House-Money from Government & 5 & 2 & 0.006 & 0.011 & 0.002 & 0.003 & 0.007 & 0.001 & 0.155 \\
\hline 14 & House-Money from Employer & 5 & 2 & 0.005 & 0.011 & 0.004 & 0.006 & 0.002 & 0.006 & 0.036 \\
\hline 15 & Personal Loan & 5 & 2 & 0.045 & 0.047 & 0.034 & 0.041 & 0.048 & 0.034 & 0.036 \\
\hline 16 & Loan from Friend & 2 & 1 & 0.036 & 0.041 & 0.035 & 0.043 & 0.045 & 0.097 & 0.112 \\
\hline 17 & Loan from Employer & 4 & 1 & 0.009 & 0.015 & 0.007 & 0.005 & 0.011 & 0.011 & 0.008 \\
\hline 18 & Loan from a Microcredit Institution & 4 & 1 & 0.009 & 0.015 & 0.007 & 0.008 & 0.007 & 0.012 & 0.008 \\
\hline 19 & Loan from an Informal Lender & 5 & 2 & 0.005 & 0.01 & 0.003 & 0.003 & 0.004 & 0.01 & 0.012 \\
\hline 20 & Vehicle Finance & 8 & 3 & 0.054 & 0.05 & 0.032 & 0.042 & 0.051 & 0.054 & 0.062 \\
\hline 21 & Overdraft & 8 & 3 & 0.042 & 0.039 & 0.016 & 0.025 & 0.031 & 0.017 & 0.035 \\
\hline 22 & Store Card & 5 & 2 & 0.194 & 0.226 & 0.205 & 0.219 & 0.183 & 0.1 & 0.216 \\
\hline 23 & None of the Above (Level 1) & 1 & 0 & 0.39 & 0.408 & 0.418 & 0.367 & 0.309 & 0.271 & 0.221 \\
\hline 24 & Basic Account (Level 2) & - & 1 & 0.602 & 0.581 & 0.574 & 0.627 & 0.678 & 0.712 & 0.701 \\
\hline 25 & Intermediate Account (Level 3) & - & 2 & 0.252 & 0.281 & 0.292 & 0.318 & 0.387 & 0.418 & 0.576 \\
\hline 26 & Advance Account (Level 4) & - & 3 & 0.103 & 0.099 & 0.071 & 0.079 & 0.091 & 0.092 & 0.093 \\
\hline \multirow[t]{2}{*}{27} & General Account and Services (Summary) & - & - & 0.973 & 0.977 & 0.95 & 1.032 & 1.173 & 1.244 & 1.45 \\
\hline & Observations & - & - & 2984 & 2988 & 3885 & 3894 & 3900 & 3900 & 3900 \\
\hline
\end{tabular}

Mzansi was introduced in 2004 
Appendix 2 - Classifications and Trends of Access to and Use of Investment and Savings Financial Products

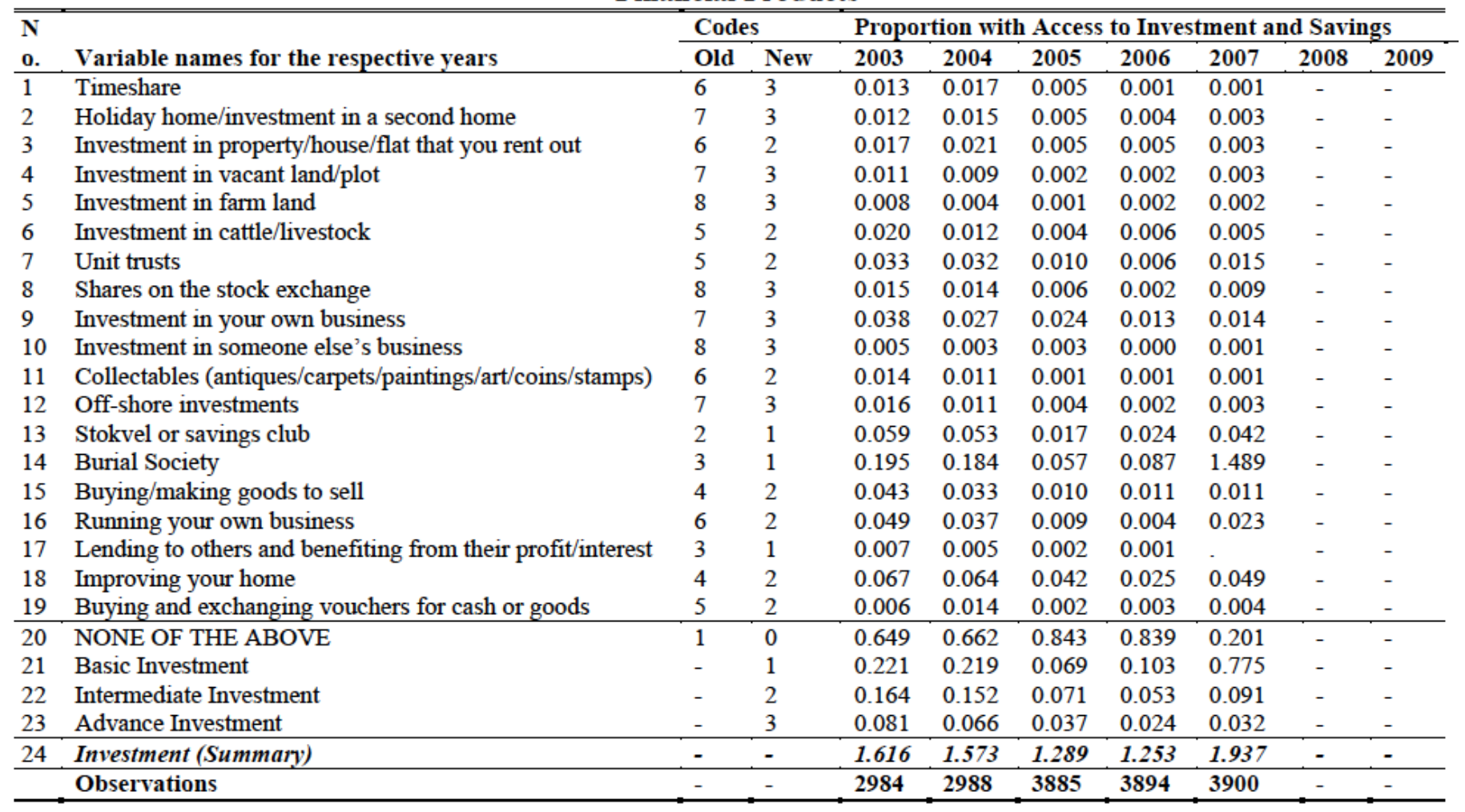


Appendix 3 - Classifications and Trends of Access to and Use of Insurance/assurance Financial Products

\begin{tabular}{|c|c|c|c|c|c|c|c|c|c|c|}
\hline \multirow[b]{2}{*}{ No. } & \multirow[b]{2}{*}{ Variable names for the respective years } & \multicolumn{2}{|c|}{ Codes } & \multicolumn{7}{|c|}{ Proportion with Access to Insurance Products } \\
\hline & & Old & New & 2003 & 2004 & 2005 & 2006 & 2007 & 2008 & 2009 \\
\hline 1 & Funeral Policy with a big institution & 4 & 1 & 0.20 & 0.21 & 0.04 & 0.07 & 0.07 & 0.08 & 0.12 \\
\hline 2 & Life assurance policy & 6 & 2 & 0.20 & 0.15 & 0.16 & 0.15 & 0.15 & 0.17 & 0.20 \\
\hline 3 & Retirement annuity & 7 & 2 & 0.10 & 0.10 & 0.09 & 0.10 & 0.09 & 0.08 & 0.10 \\
\hline 4 & Provident fund & 5 & 1 & 0.06 & 0.07 & 0.04 & 0.05 & 0.07 & 0.07 & 0.10 \\
\hline 5 & Pension fund & 5 & 1 & 0.14 & 0.13 & 0.09 & 0.09 & 0.11 & 0.11 & 0.14 \\
\hline 6 & Endowment/investment policy & 7 & 2 & 0.09 & 0.10 & 0.08 & 0.04 & 0.03 & 0.05 & 0.03 \\
\hline 7 & Home owner's insurance & 6 & 2 & 0.11 & 0.10 & 0.05 & 0.07 & 0.06 & 0.07 & 0.09 \\
\hline 8 & Medical aid & 6 & 2 & 0.16 & 0.16 & 0.14 & 0.14 & 0.13 & 0.12 & 0.16 \\
\hline 9 & Hospital plan & 8 & 3 & 0.06 & 0.05 & 0.04 & 0.04 & 0.03 & 0.03 & 0.03 \\
\hline 10 & Medical insurance & 8 & 3 & 0.03 & 0.03 & 0.02 & 0.02 & 0.02 & . & . \\
\hline \multirow[t]{2}{*}{11} & Insurance taken out to maintain credit & & & & & & & & & \\
\hline & payments & 6 & 2 & 0.02 & 0.03 & 0.01 & 0.01 & 0.04 & 0.09 & 0.08 \\
\hline 12 & Disability insurance & 8 & 3 & 0.05 & 0.06 & 0.05 & 0.04 & 0.04 & 0.04 & 0.04 \\
\hline 13 & Educational policy & 5 & 1 & 0.03 & 0.02 & 0.02 & 0.02 & 0.03 & 0.03 & 0.02 \\
\hline 14 & Household content insurance & 8 & 3 & 0.12 & 0.10 & 0.10 & 0.09 & 0.09 & 0.09 & 0.11 \\
\hline 15 & Car insurance & 7 & 2 & 0.14 & 0.12 & 0.11 & 0.13 & 0.13 & 0.12 & 0.12 \\
\hline 16 & NONE OF THE ABOVE & 1 & 0 & 0.65 & 0.67 & 0.73 & 0.71 & 0.68 & 0.68 & 0.66 \\
\hline 17 & BASIC INVESTMENT & - & 1 & 0.27 & 0.27 & 0.13 & 0.17 & 0.20 & 0.20 & 0.24 \\
\hline 18 & INTERMEDIATE INVESTMENT & - & 2 & 0.28 & 0.25 & 0.24 & 0.24 & 0.25 & 0.26 & 0.27 \\
\hline 19 & ADVANCE INSURANCE & - & 3 & 0.16 & 0.14 & 0.13 & 0.12 & 0.12 & 0.12 & 0.13 \\
\hline \multirow[t]{2}{*}{20} & INSURANCE (Summary) & - & - & 1.80 & 1.72 & 1.65 & 1.67 & 1.70 & 1.70 & 1.74 \\
\hline & Observations & - & - & 2903 & 2896 & 3885 & 3894 & 3900 & 3784 & 3814 \\
\hline
\end{tabular}

Appendix 4 - Trends of Financial Perception and Financial Behaviour

\begin{tabular}{|c|c|c|c|}
\hline & Financial Perception & Financial Behaviour & T-Test \\
\hline Year & $\begin{array}{l}\text { Proportion of Respondents who } \\
\text { disagree with the notion that one } \\
\text { can live without a bank account }\end{array}$ & $\begin{array}{l}\text { Proportion of Respondents } \\
\text { who Trade-off basic things } \\
\text { in order to save }\end{array}$ & $\begin{array}{c}\text { Difference in Proportions } \\
\text { between Columns } 2 \text { and } 3 \\
\text { (Level of Significance) }\end{array}$ \\
\hline 2003 & 0.47 & 0.24 & $19.70(0.00)$ \\
\hline 2004 & 0.46 & 0.23 & $20.76(0.00)$ \\
\hline 2005 & 0.50 & 0.26 & $23.80(0.00)$ \\
\hline 2006 & 0.50 & 0.26 & $23.39(0.00)$ \\
\hline 2007 & 0.56 & 0.24 & $31.22(0.00)$ \\
\hline 2008 & 0.54 & 0.26 & $27.83(0.00)$ \\
\hline 2009 & 0.52 & 0.23 & $29.56(0.00)$ \\
\hline
\end{tabular}

